\section{(1) \\ George Fox \\ UNIVERSITY}

\section{Digital Commons @ George Fox University}

Western Evangelical Seminary Theses

$5-1-1957$

\title{
A Study of the Biblical Basis for Tithing
}

John W. Anderson

\section{Recommended Citation}

Anderson, John W., "A Study of the Biblical Basis for Tithing" (1957). Western Evangelical Seminary Theses. 53.

http://digitalcommons.georgefox.edu/wes_theses/53

This Thesis is brought to you for free and open access by the Western Evangelical Seminary at Digital Commons @ George Fox University. It has been accepted for inclusion in Western Evangelical Seminary Theses by an authorized administrator of Digital Commons @ George Fox University. For more information, please contact arolfe@georgefox.edu. 
APRTOVDD BY

Mejor prosessor:

Kermeth P. Weschs

Co-oporative Reader:

Miedere Wypleop

wofeasor of meste form:

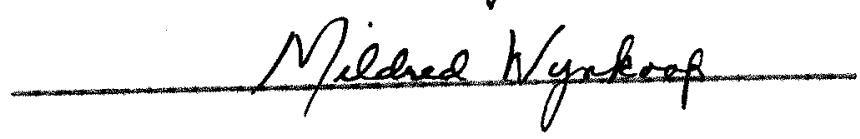




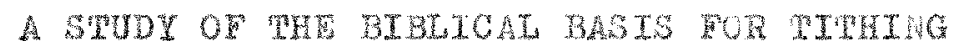

\title{
by
}

John W. Andoron

\author{
Mhesis \\ resented to \\ the waculty of the \\ Westorn tanedical semang
}

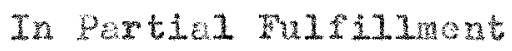

of the Requirements ror the Degre

Bachelor of Divinity

Portand 22, oregon

May, 1957 


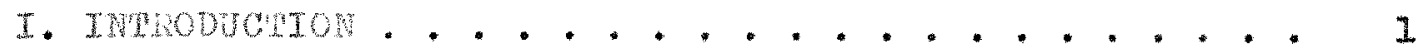

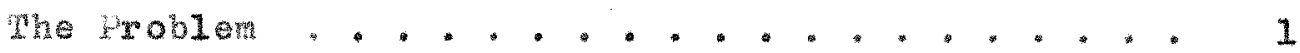

Justification of the Study ............... I

Sources of Data ....................... 1

Rasto Aseumptions .................... 2

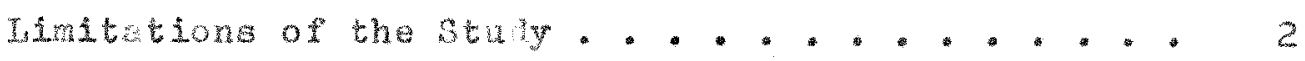

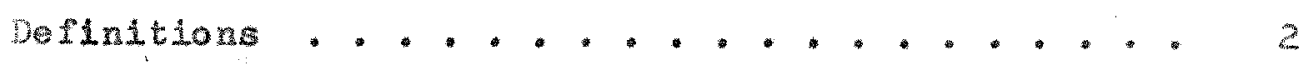

Statarat of Organization ............. 3

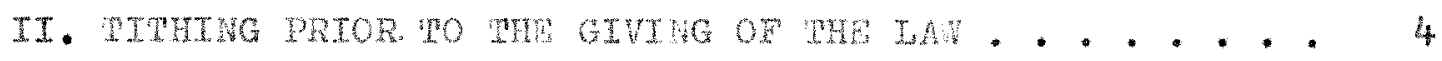

oftarings of Caln and Abe1..............4 4

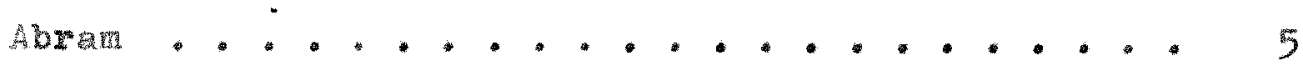

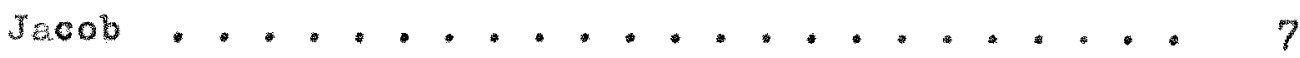

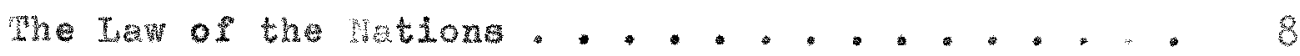

Sumathy

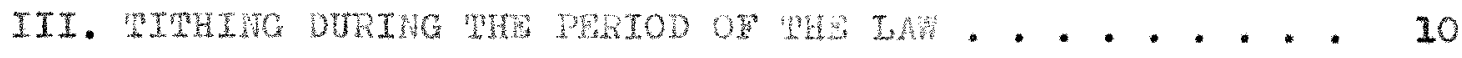

Mosaie References to 4 thing . ............ 10

Leviticus ..................... 10

lumbers . . . . . . . . . . . . . . . 1$]$

Deuberonomy ...................... 12

Comparisons of the losale References....... 15

Tater old restament hererences........... 16

Amos...................... 17

Second Chronicles . . . . . . . . . . . 17

Nohemin......................... 19 
Ma1ackin..................... 20

sumaraxy ........................... 21

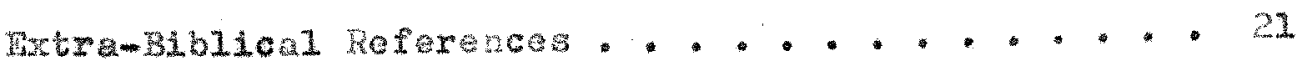

Apocrypha ..................... 21

lalaud ..................... 22

Sone peaching on tithing During the period of the

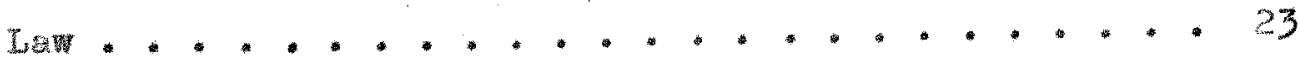

withing and worship ............... 23

whe Method of paying dithes.......... 24

Wes of the Tithes ................. 25

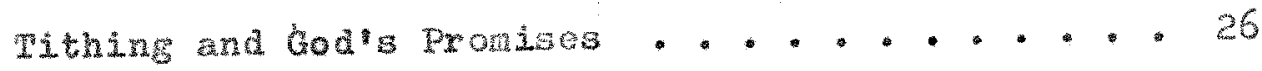

Sumary ...................... 28

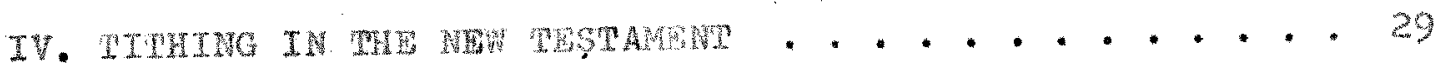

Jesur and the mithe................. 30

Teachnes by Jesus ............... 30

Jeaus ang stevardship................ 32

Jesus and the Lew................. 34

Paul and ruthing . . . . . ........... 35

me wolstie to the Kebrews .............. 37

Suramary ......................... 39

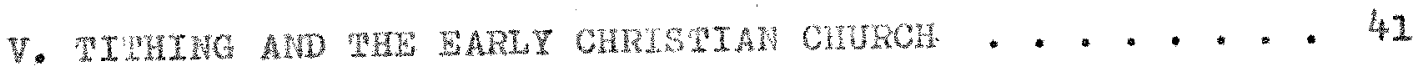

Church Fathers . . . . . . . . . . . . . 41

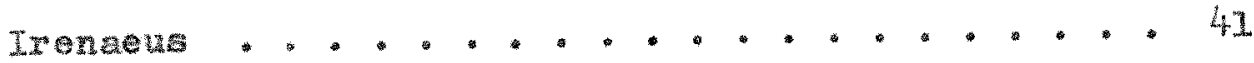

clement of Alexardrod.............. 42

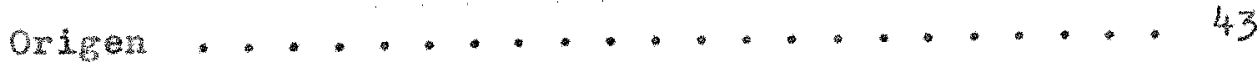

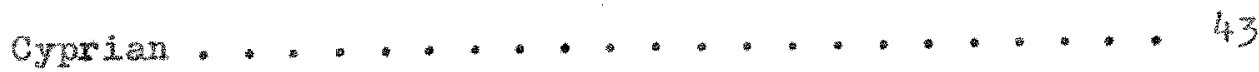




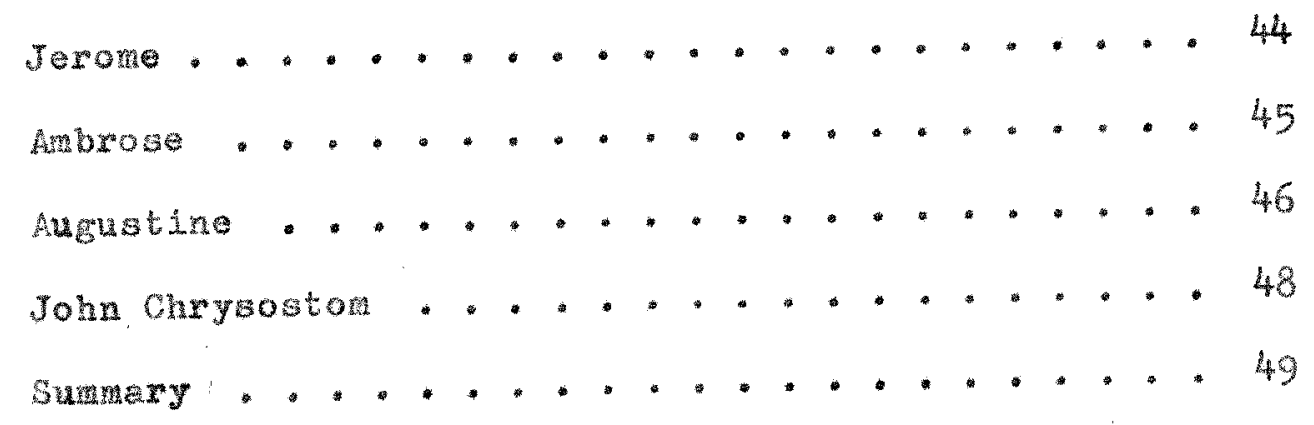

Church Counc11s . . . . . . . . . ...... 50

The Council of Macon................. 50

The council of seville................. 51

whe council of ment.................. 51

summary ..................... 52

VI. SUMHAR MD COMCWBSONS . . . . . . . . . . . . . 53

Summary .......................... 53

withing pror the the Ging of the Law. . . . . 53

Tithing During wo period of the Jaw . . . . . . 54

Tithing in the New pestanent. . . . . . . . . 56

withing and the Early Christian Church. . . . . 5 ?

Conclusions . . . . . . . . . . . . . . . 58

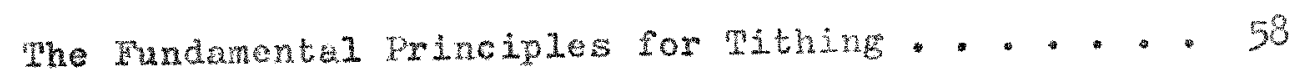

The Values of pithing ............... 60 BTBLIOGRAPLI . . . . . . . . . . . . . . . . . . 62

supplemeatary Blbilography . . . . . . . . .". 63 Book .................... . . 63

incyelopedias .................... 64 Penphlets . . ................. 64 


\section{CHADILE I}

\section{THEODWOEION}

Phe Problem. Nithing is included as potion of a christian"s obligator to the church by most chrotitan groups of todey.

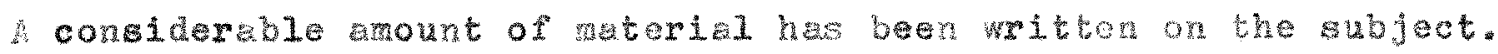
mese waterials vary in aprodch and huterpetation. It was the author's purpose to Tind the Blolical basts and toaching for tithing, both in the old and New lestancnto.

Justinication of the study. Mhe reperbed referonces to

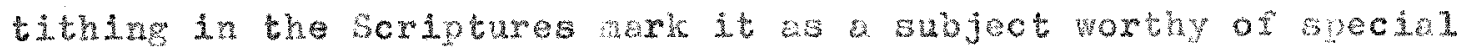

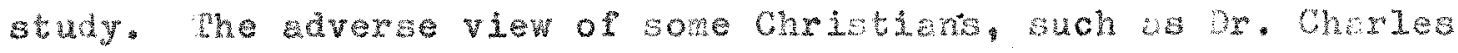

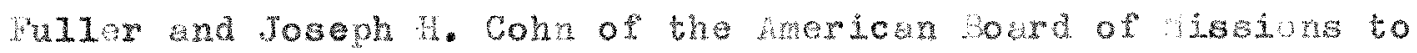

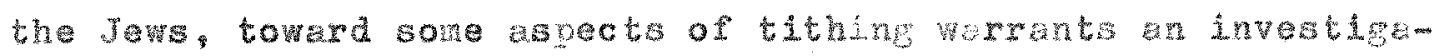
tion of the Biblicel teaching.

The author develoged an imerobed trbexest in the subject

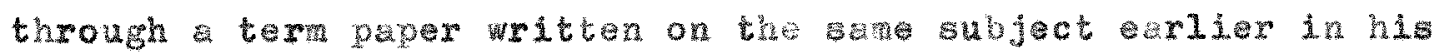
seminary studies.

Sources of bata. Ihe primary gource or data was the smer-

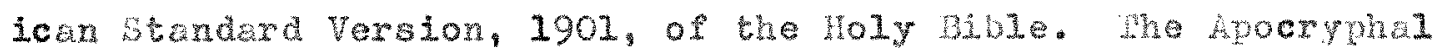
books of the old lestanert, as revised in 1894, more anso included. Funerous volumes on bhe tithe as well as books dealing whth

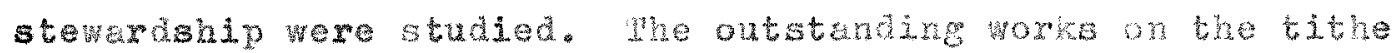

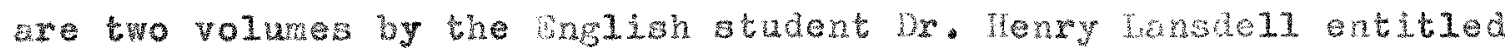

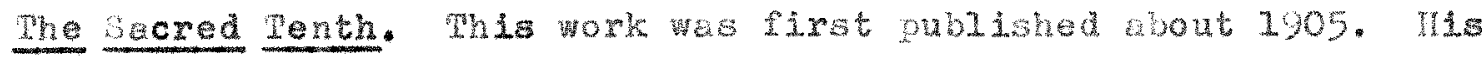


work traces the history of the the inom antiquity formar to the twentieth century. Werly every source of aten conalted

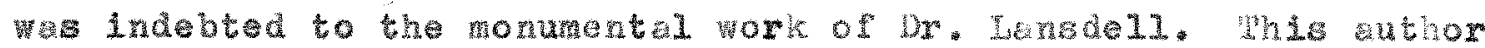

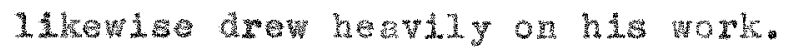

Basic Msountions. The athor a basic asumpton was that

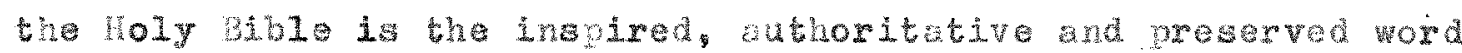

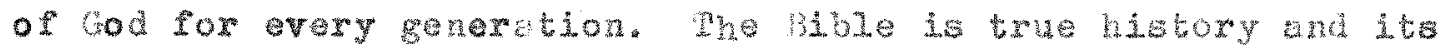

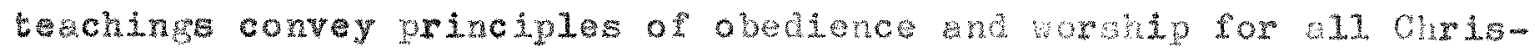

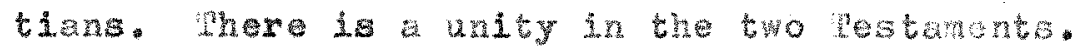

Limitations of the 3tudy. Mhe study was bascaliy a bibe study. Whe references in the Blble axe few jumber, fragentary in explaration, and often giver in an indirect marar. The

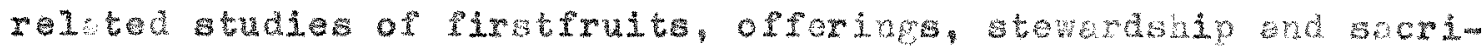
fless vere not studied. These toplcs offer an aran for aditiond suture study.

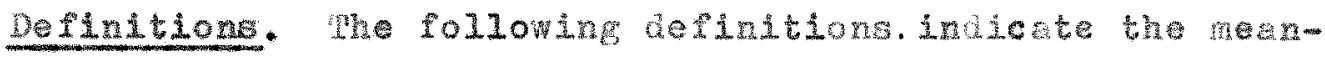
Ings of some terms as used in this thesis.

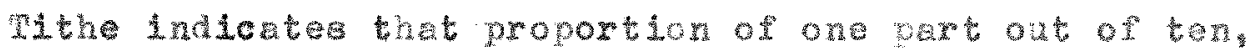
or a centh in relation to inoome.

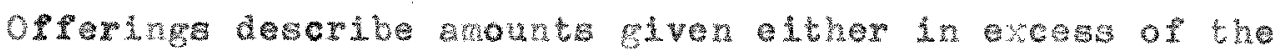
tithe, or separately from the tithe

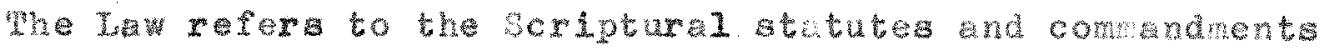

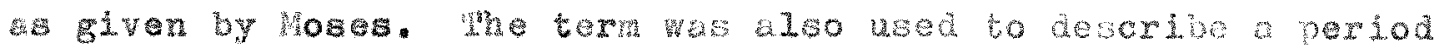
of the extending som the dey of hoseg untal the birth of the Christian Church thentecost. 


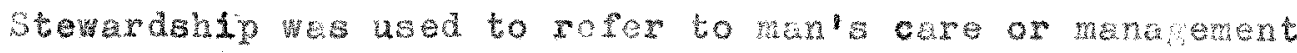

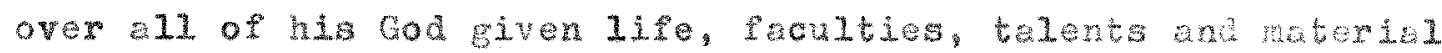

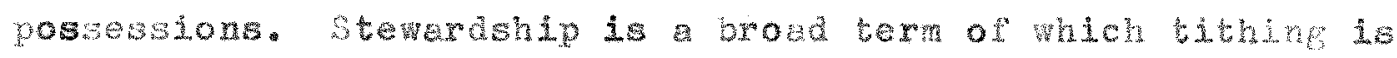
but one apect.

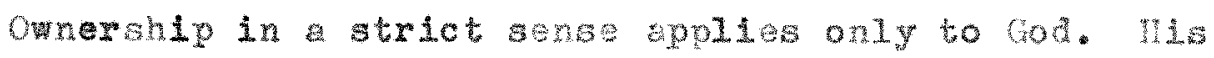

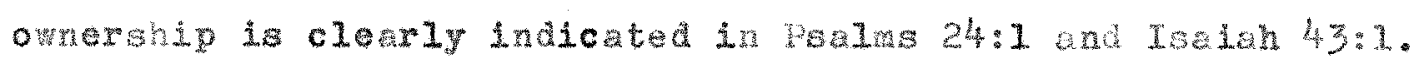
Whe atorehows was. term used to designote the place

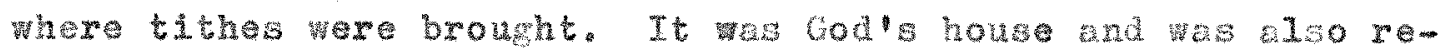
pared to as the trearure-house or chamber.

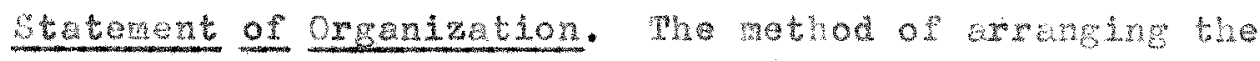

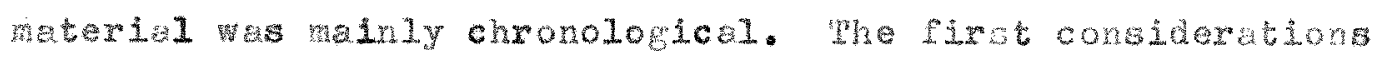
deat with the tithing practices priox to the tare di loses. The techings on tithin: during the pexiod of the raw wore considered next with special reperewces to the three troes or tisthes

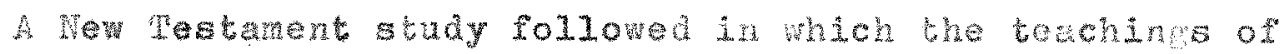
Jesus and pul were noted, A study of the lebrew letcer was also included in this chapter.

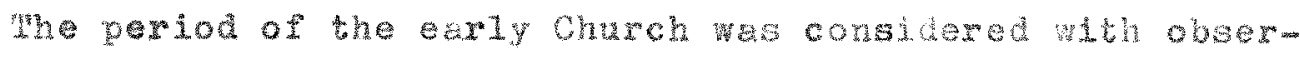

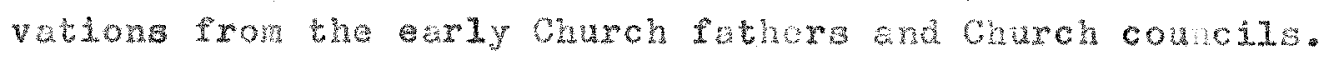

Whe final chaptex contans the findings fron the rour dix-

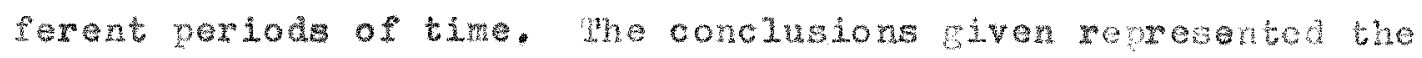

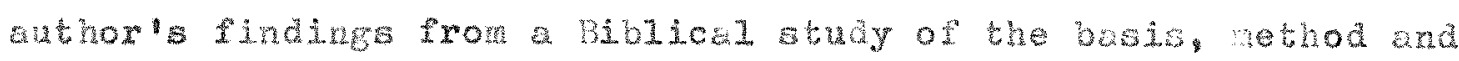

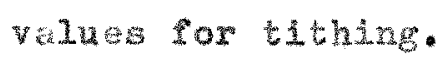




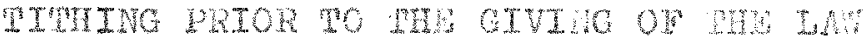

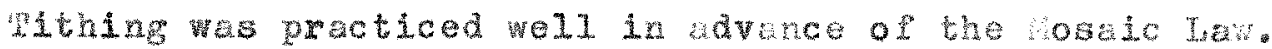
This is clearly chown in the accounce of tithing by hrohen and Jacob. Fhe exly history or bhe nutione outside the Jewah wa-

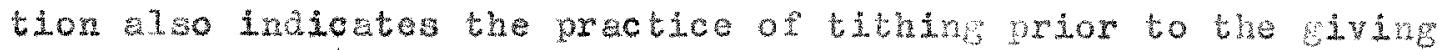
of the Law. This chapter relabs the prectee of thing aring bhat exply perpos.

\section{Osterings of Can and Avel}

The first Blble referene to the ofering of matorial

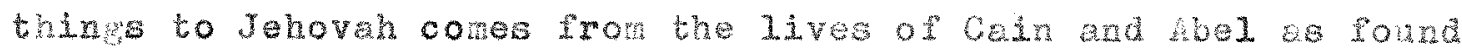
in Genesis $4: 1-7$. The real reason for the bringing of these of-

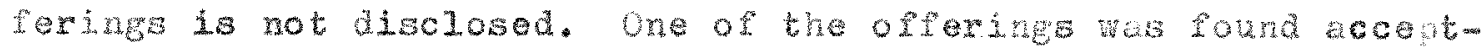

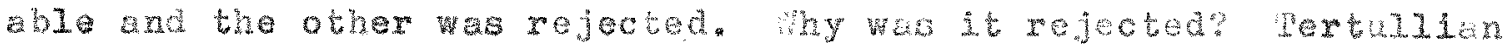
In the thira century wrote thet cod rejector the aderifice of

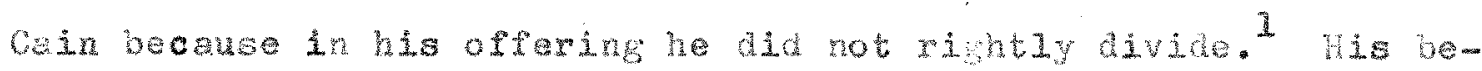

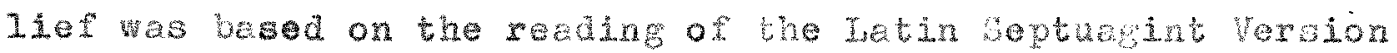
whon reads

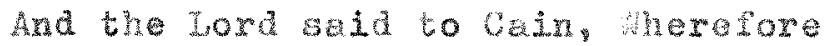
didst thou becone vexed, and wherefore

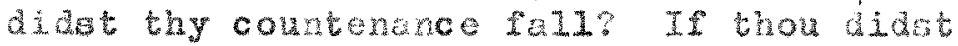
rightly offer, but didet not rightiy divide, diast thou not Bin? Told thy peace?

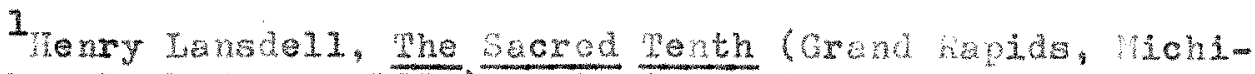
gen, Baker 3ook Nonse, 1955$)$, val. T. p. 39.

Ibid. D. $40:$ Cenesis: $4: 6-7$. 
Whe sare passare in the hmorican standird Verslon follows:

And Jehovan gaid to Culn, why art

bhou woth? and why is try countensice

fallen? It thou coest well, shall it

not be lifted ay and if thou docot

not well, sin coucheth at the loor:

and unto the shall be its lesize, but

do thou rale orer it.

Whe author of the Rolstle to the Hebrews wote thet by

faith Abel offered unto God a more excellentserisice than tain. 1

whe thought that the septuagint rendering wint refor to tithing

was great anoun that at the commil of sevilie, held sbout 590

A. D., a canon was passed which would have the curses inflicted

upon cain heaped upon any who faled to tithe in that day. 2

Abe1's offering was acceptable becaude it came as an act

of worship and arise, prompted by an awareness of the combinud

mercies and gits of Almighty cod. It may wall have ben more

particularly acceptable in thet he "xightly atuded" his abotance in bringing his of pering

Axam

The tithe is iret mentioned in the Bible in the fourtecnth chapter of Genesis, over four hundred year berore moses comanded the children of Itrael to tithe, and before there were any Jews or Levites. Whe scriptures relate that certain kinge relded sodon, and carried way all the inhabitants, Including Lot, Abrants

\section{$1_{\text {Hebrews }} 11: 4$.}

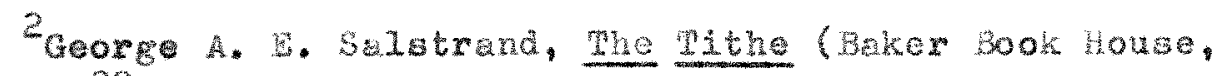
1952), p. 20. 


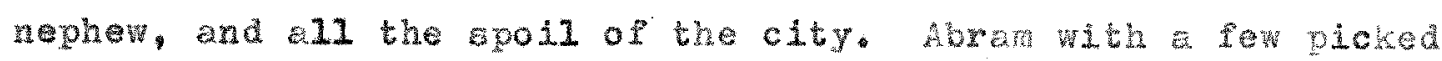

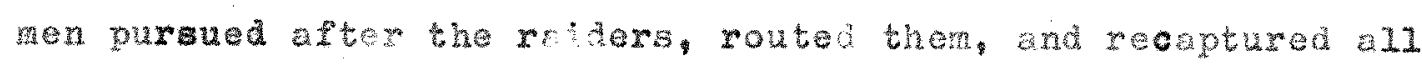
the pereons ant 11 the goods. As he returred he met velch dak priest of God Most High, and gave him a tenth of ell.

Fisst mention of the tithe appersin in the account wh perfect naturalneso and without explandton, as it it ware a ready ar accepted and well understood instituson. Why was it a tonth and not sone other proportion. The answer to this ausation is un unown. It is known that in most sacred hour that the man selscted of God to be the father and fourder of a chosen race took tenth and gave it to God's priestas an offering to cod. It Is further known that the account of this event was allowed by the Holy Spirit to be included twae sn the inspised record, wh evident aporovel.

Cortein observations can be stated from the iroident of Worem paying a terth. Pirst, in paym a tenth Abran recognized an authority higher than hinselt, nemely felchizedek priest of the Most High God. secondy, he gave tithes as a confession of obligation to God who had bean his helper in the time of read. Whe rictory so recenty won was not blogether his ovid. Inirdy. Mbram did not retain any of the captured coods for hinsels. though he could have. During the brief time Abran xept the spoils he gave cod a tenth of thom. Mhe natter of onnership,

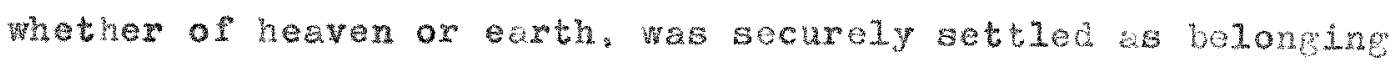
to the Most High cod. When Abran gave his the he acknowared cod"s ounership. 
Abrara 11 ved prior to the glving of tho law by Mosos.

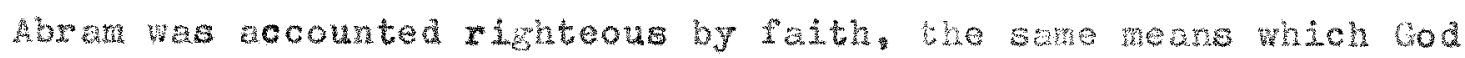

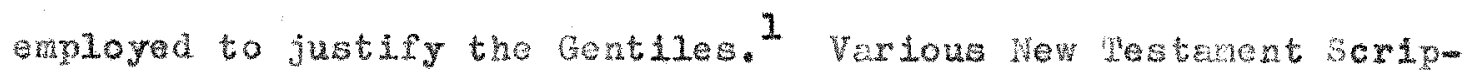

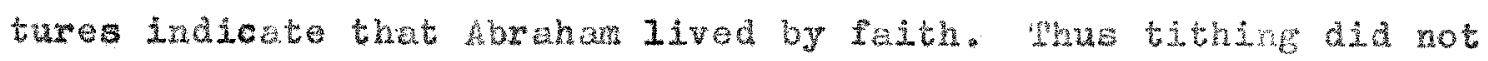

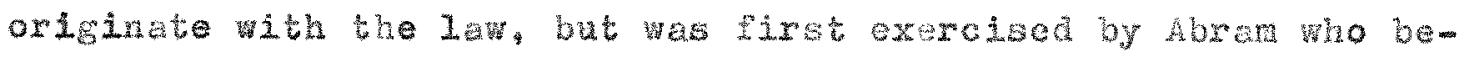
cance the fother of the falthint.

\section{Jacob}

mhe second definite reference to tithing in the enthe oo-

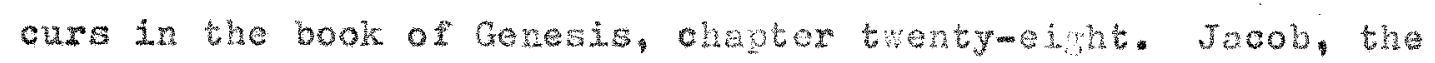

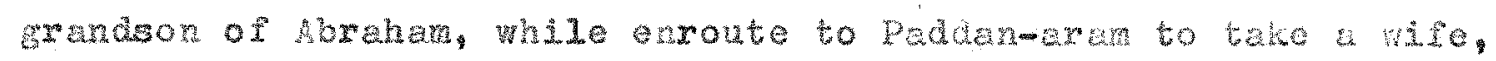

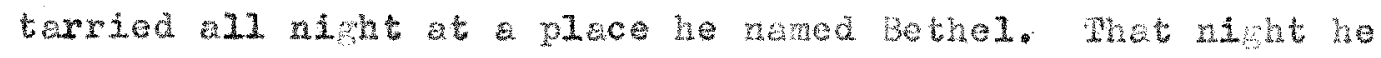
areaned thet a lader was set on the axth, and the top of it

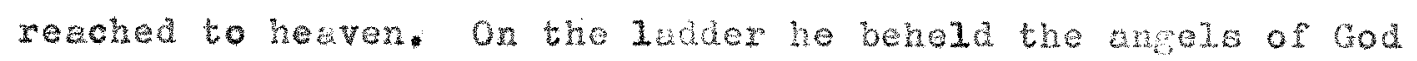
ascending ard deseending Above the laddex stood the Lord annoumeing that the Iand were Jacob was xesting would be givan to Jacob and his seed. The next morning Jacob mad a triple vow.

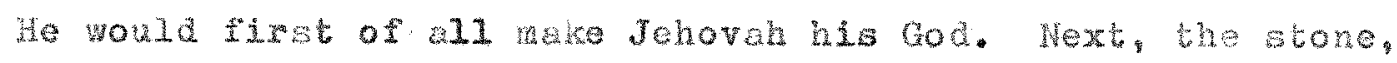
which had served as his p1110w, was orected as a p112ar ard dew clared to be God house, the thixa von was a definite promise to gave a terth to God of all that God mould give har.

Jacob could think of nothing that woula more surely neet the approval of God than that he would give God a tatth of ell that God should bestow upon hith Salstrand says that Jacob

\footnotetext{
1 homeng $4: 1.1$ Galatians $3: 7,9:$ Hebrews $7: 5-9$.
} 


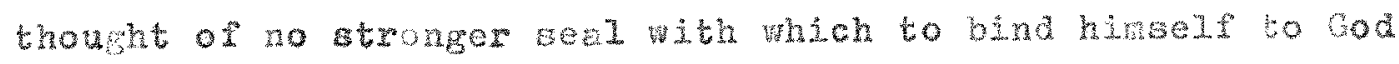
than to row to give God the terth. 1

A conperison of the tithing of horam and Jacolo reveoled

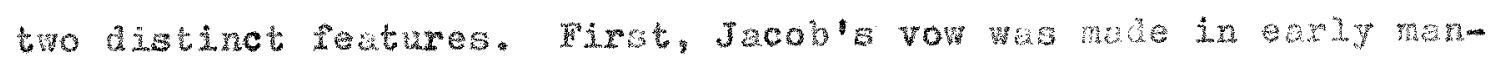
hood and was to be constinued for all his Iifetine, not for the

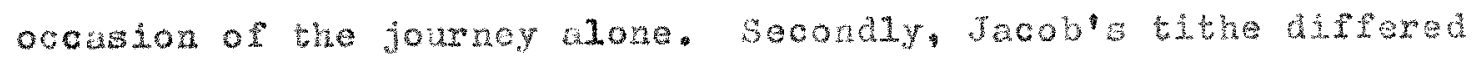

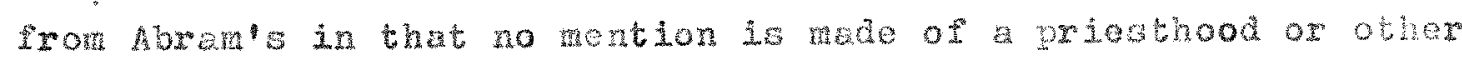
recaiver. Jacob's tithing, like that of Abram, was peroruea prior to the giving of the Lav by Moses.

\section{The Law of the Nations}

Tithing was practiced by the nations of antigutey that wnen nothing about the waw of Moses. These metions included anch

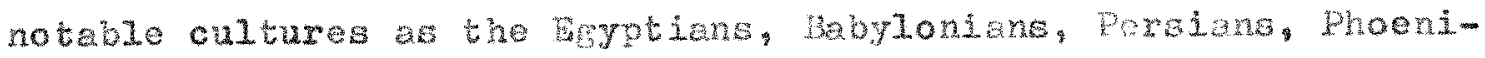

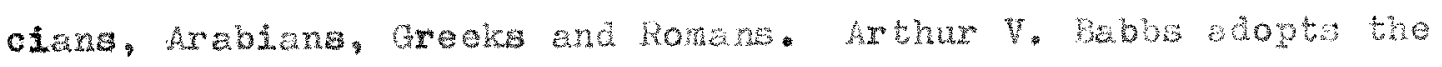

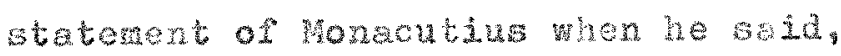

Instances are mentoned in history of some yetions who wid not ofien sacrisces: but in the amals of all times

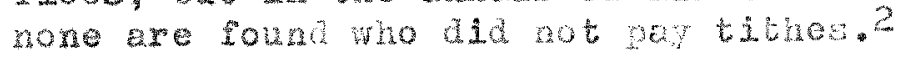

Dabos commenting on the universelity of tithing sumaxigen his Pindings as rollows.

We have incovared that the idea of the tithe covered all of the ancient world, from the extremes of lestern murope

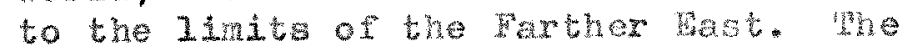
arcients, even those not lebrew by birth hat the daea that to neglect the trithe

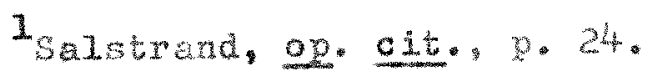

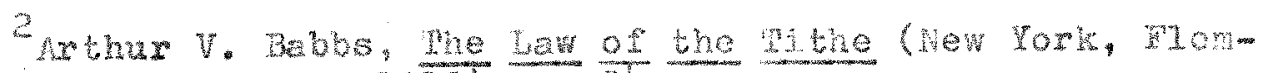
ing $\mathrm{H}$. hevell compan, $19 \overline{12}, \mathrm{P}, 24$. 


\begin{abstract}
would bring isagter from cod. The universality of the protice of tithing axgue that there was and 1 a deep in the consclousness of man a sense of obligation. Since this fecling of dep oblim gation to God was so wide-spred and tat the same the so ancient, it rollows that in the morning time of the world, cod, by a revelation of Mis will, had promugated wnd enforced the law of the tithe for all the sone of ren:...1
\end{abstract}

When the number of nations whose histonies testify to the presence of tithing in their entiquities is viewed, the question of the comon acceptance of a tenth is raised. The nations that were so widely separated in meny ways found a comon expression in the practice of tithing in vried forms. This argues a comon source for the practice and principle of tithing. A logical inference is that that source tas God. The pratice of the nations was in harmony with the practice of Abrean and Jacob, though the motives mey have varied.

\title{
surwary
}

The record of Genesis relates two distinct accounta of the practice of tithing. In abution to these references there is a strong alusion to the tithe in the offerings of Cain and hbel. In haraony with the early Biblical acounte of tithing was the practice of tithing anong the arly nations. These facts axgue for the significance and imortance of this institution which has been traced into the most resote periods of known history.

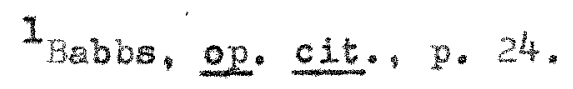




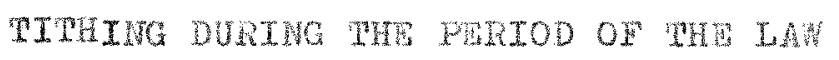

The logal period of the history of Iareel comeroed with the giving of the Law on Mount sinai by God to hoses ard continued until the bith of the Christian Church tet pentecost. Isras as a notion needed cartaln law ard rulos for hor gudace. Anong these laws and rules was the law of the tithe. In addition to tithes Iorael had firgtruits, offerlngs and sacifices with wich to workip God.

Mosiac References to rithing

Leviticus: This book contanin only one reference to tithing . Leviticus $27: 30-33$ follow:

And all the tithe of the Iand, whether of the sed of the Iand, of of the frut of the tree, is Jehovahs: it is holy unto

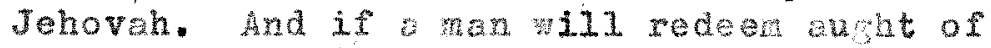
his tithe, he shall ad unto it, the fifth pat thereot. And all the tithe of the herd or the Nock, whatsoever passeth under the rod, the tenth shall be holy unto Jehovah. He shall not seerch whether it be good or bad, neither ghall he change it: and if he change it at all, then both it and thet for which it is changed shell be holy; 1 shall not be redeened.

This passage revers several depute inatructons in regard to the tithe. Firct, a tenth of the produce of ane land, whether of sed or frutb, was clamed by cod gecondy, it was to bo regarded as holy and set apart for min. mhindy, if the

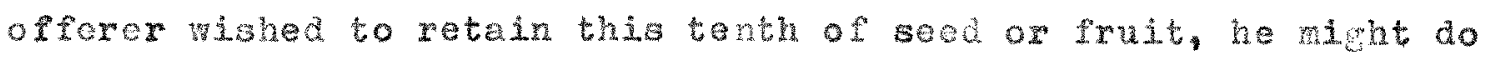


ao by paylng its value and ading one-fifth to the tithe. In the fourth place every teath animal of the herd ox llock wab to be

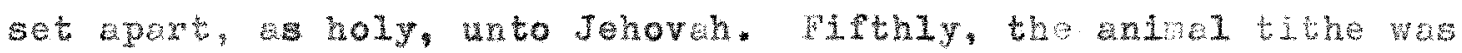

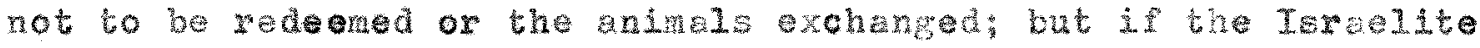
presumed to chage the andmin, not only the ththe andat, out

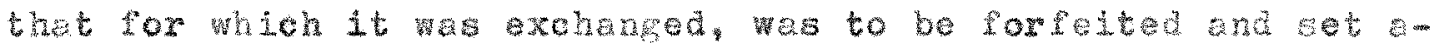
pext to Jehovah.

踏bers. Two consecutive references occur in this book.

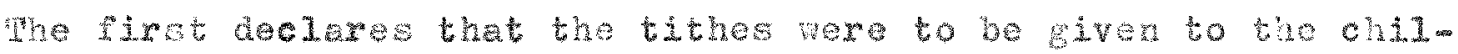

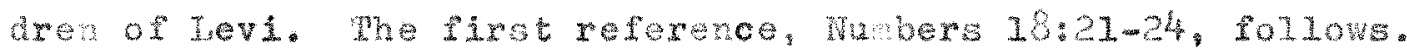
And unto the chiluren of bevi, beholis I have given all the tithe in torat for

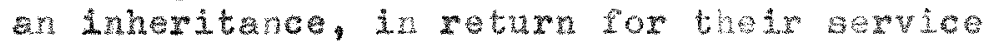
which they serve, even the service of the tent of meting. And hencolorth the childron of Iaxeel shall not come nish the tert of weeting, lest they bear sin, and die. But the levites ahli a the arrice of the tert of meeting. and they ahal bear bheir inioulty: 1t ghal be a statute for evor throughout your genertion: and whong the

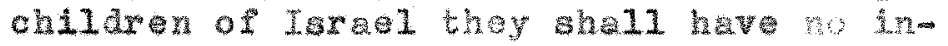
heritance. For the ththe of the children of Israel, which they ofter as a hesvem

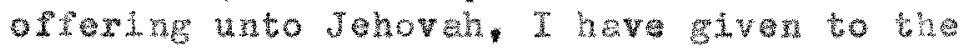
Ievitas for an inheribance: ther yore $x$

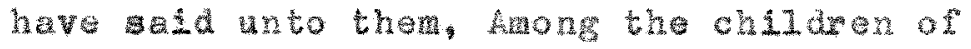
Iarael they ahall have no inhastance.

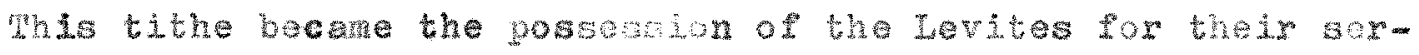

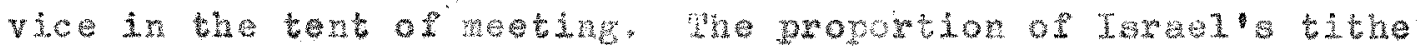

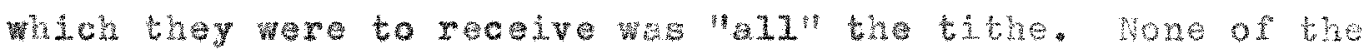
ththe of the prokuce of the land, or the increase of the nexd ot

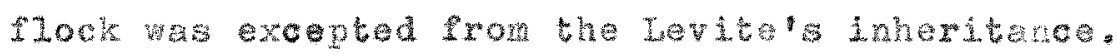

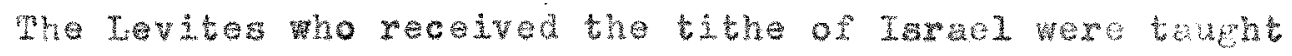


by Jehovah to tithe the the. This Le told in Numbrs 18:25-28:

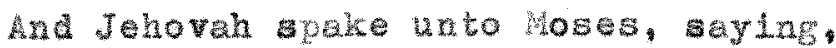
Noreover thow ghalt spod unto the sevites, and say unto them, when ye take of the chlldren of larael the tithe which I have given you from then for your inleritance. then $y$ bhell of it for Jehovah, tathe of the tisth. Ana your heste-offering abll be rackoned unto you, as though it whe the gran on the threshlng floor, wat as the fulness of tho winepress. Thus ye also bhall ortar hetav-offering who Jehoveh of all your ththes, which ye cecive of the children of Isxael and thereot ye shall elve Jeho-

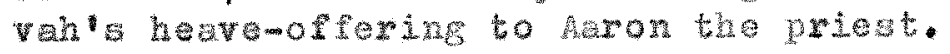

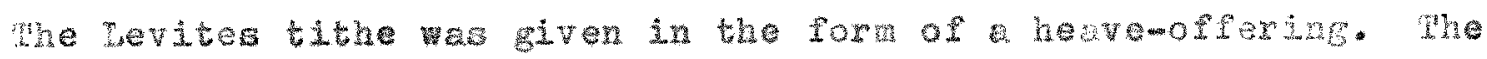
Levites had no land produce to bithe, but this was rockored as such for thew. Aeron the priest recelved their heave-oflexing.

Douteronomy: Isracl wes inctmeted to toring thejp tibhes to the central place or worship. Mhis instution is found in Denteronouy $12: 5,6$, as follow:

But unto the place which Jehovah your sod shall choose out of all your tribes, to put his nane there, even wnto his hebitathon shell ye seck, and thither thou shalt cone; and thithex ye shall bring your

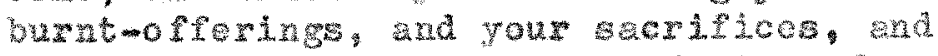
your ththes, and the heave-offering of you hand, and your vows and your freeWi1 of feringe, and the firstilngs of your herd and of your flock...

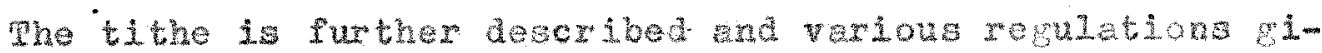
Wen in Deuteronony $14: 22-27$, quoted below.

Whou shelt surely tithe all the increase of thy seed, that which coneth forth from the field year by year. And thot: shit ext before Jehovah thy lod, in the place which he chall choose, to cuse his

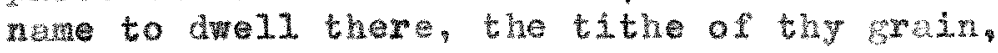


of thy new whe, and of thing oll, and the Pirstings of thy hera and of thy flock thet thou meyegt leara to fer Jehovis thy God always. And in the way be too Iong ror thes, so thet thou art not able to carry it, because the place is too far frow thee, which Jehoveh thy God shall choose, to set his nive there. when Jehovah thy God shell bless thee! then shalt thow turn it into noney, and bind up the money in thy hard, and shat go unto the place which Jehovah thy cod shall choose: and thou shelt bestow thy money for whatsoever thy soul asketh of she and thou shalt oct there berore Jehovsh thy God, and thou shalt rejolce, thou and thy household. And the Levite that is ithin thy gates, thou shet not forsake hist for he hath no portion nor inhoritance with thee.

This description of eating a the does not constitute pardiel of tithing as thought of by present day christicns. Wut it ad constitute an expense that had to be net by the Hebrew for rem 11gious purposes. This the consistod of the reary increase of produce from the field, whether of grain, whe, ofl, or the first1ings of the herd and fock. It was to be aten by the oferer his household ana the Levite at the apponited pace of workhip.

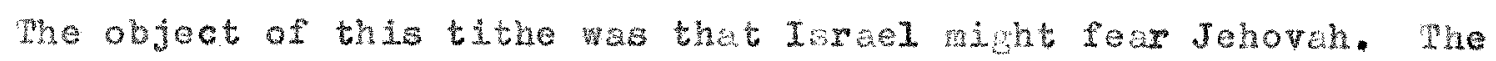
tithe could be exchenged for money, to be expended at the conter of worship ror feasting, it the offerer was unable to carry his ththe, or if the abstance were too great. ahis was bine of

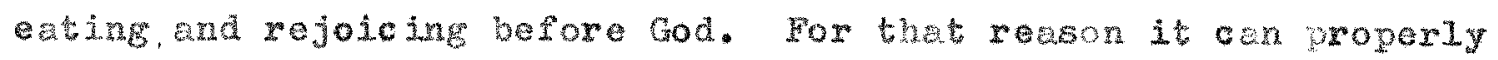
be called a festival thene. The primary propose ot the fostivals where the tithes. were brought was stated by Landell as:

Whe primary end, theresore, of the festivals was to foster religious principles and to furnish a time ard place for 
social observarices and the offoring of sacrifices, all belag done in wecogultion of God's bounty and as acts of Tealty and worship to Bin. 1

A further reference to tithrig is found in the paragraph

Followis the last Scripture auted. That paragraph, Deutoronomy $14: 28,29$ is guoted beIow.

At the end of every three years thou ahalt bring forth all the tithe of thine increase in the same year, and shelt lay it up within thy gates: and the Levite, because he hath no portion nor inheritance with thee, and the soJourner, and the futherless, and the widow, that are within thy gates, ahall cone, and shall eat anc be satisfied: thet Jehovah thy God may bless thee in all the work of thy hand which thou doest.

This passage toaches that a tithe of every third yeex"s increase was to bo lajd up tat home. Whis tenth was to be shared by the levite, the sojomrner, the fathoriess and the waw the object of this tithe was that. Jehovah wish bless the woris of the tithex's hands. This tithe has bean colled the poox tithe. The last reserence to tithing in the book of Deuteronomy is found in chapter twenty-gix, verse twelve, 知 follows.

When thou hast made thend of thithig all the tithe of thine increwe in the third year, which is the year of ththing, then thou shalt sive it wito the Levite, to the sojourner, to the fatherless, anct to the wiow, that they may at within thy sotes, and be rilled.

The recipients of this tithe ars the save as chose named

$1_{\text {Lensde11, og. cit. }, 0.6 \%}$ 
In Deuteronomy 14:28, 29. whe time of tiching was 1 ikentse the

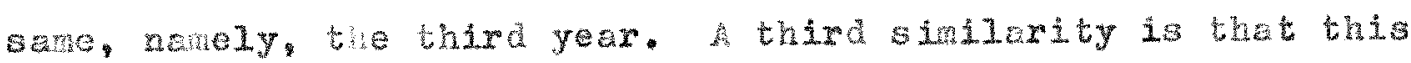
tithe was also kept at the tither"s hore. Whe exprescion "bhe year of thing occurs only in this paseage. The expression apparenty applied to every third yeax.

The Kng Janes Version veries 1 inhty in the rendering of this passage. The varibton occurs in the was on thithes" (KJV), rather than "the" (AgV). The pluxal readering would Iridcate the exiatence of nore than one form of tithing.

Comparisons of the Hoelac kelexences. The books of Heviticus, Wubers and beuteronony describe four tithes: lirst,

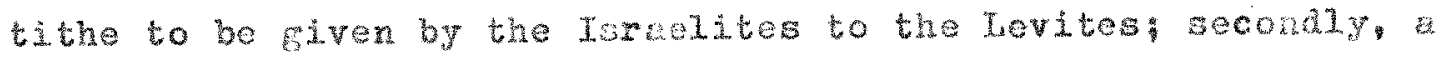
tithe of the tithe by the Levites to Maron the priesti thind

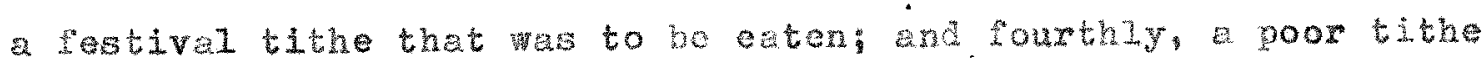
which was observed every thire year. Hach of these tithes applied to the Iareaites except the tithe of the ththe pad by the Levites. The following titles he sisisted in identirting the three tithes pad by the Isratites the Levitical tine the festivel tithe and the poor tithe.

whe specific inems to be tithed by the paynt of each of these tithes were studed. The Levitical tithe included tho seed of the lard, the frut of the tree, the tithe of herd and of tho flock. The restival the included the increase of tho secd from the fields, the tithe of grain, nev whe, oll and the pirstinge of either a herd or rlock. The poor ththe was stated to be the tithe of one increase in the thixd year. Nhis comparison shows 
thet virtually the same itom are subject to the tithe in each 1nstrnce. Thus the various pasares do not repreant tithing legislation covering difterent forms of Iivelihood or getm. Bach

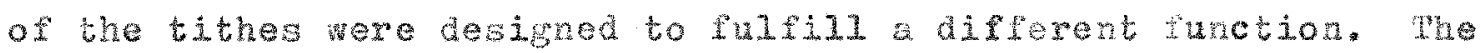
Levitical tithe rrovided lox the care of the Levites and resesta: the restival ththe wes pexsonaly consuned by she tither's household and the Levites in fellowshlp and the poor tithe was reserved for the poor whows, futherless, stragers and the Levites. The Levites were entitled to a porion of eac of the troe tithes. The sacredness of each of the ththes was clearly designetod. This is especially true of the Levitical tithe which was stated to be holy unto Jehovah. Mhe material care of the Levites was male dependent upon the tithes of the people. The sacreaness of the festival tithe was traght by rouning it to be eaten at the central place of workin. Whe purpose of the pestivit ththe Was that the people night learn to fear God. "ihe third tithe, or poor ththe, was acred as a neans whereby Cod ming bless the labors of the peopla.

Later old Testament References

In adation to the teachings found in Leviticus, Numbers, and Deuteronony some leter xelerences to tithing were made by Anos, Nehowiah, Malachi and the wher of second Chronicles. These reserences do not introduce wew tithes, but do reuber adational insight into the tithing pxactices.

The mords of samuel to the people when they clusared for 2. kng indickte that ho reared the kinge would wisuse the tithe. 
Samuel waxed the people that a seed and of the flock and ase it for the supont of his servats. 1 The people would be reduced to the position of servents and repret the fact that they asked for a king conditions such as these apparentiy did occur in the deys of Anos.

Mros. The prophet Amos was active in the reign of kings Wrain and Jeroboam. This places hros historically some six or seven hundred years after the eiving of the Iw by woses. No disect relerence to tithing ocured during this interval. Amos spoke these words:

Come to Bethel, and tratagress; to Gisel, and muttply trenswessions; and bring your sacrifices every torning, and your tithes every three divs...2

The context of these words sugeests thet the people weat on in their rebellion, aven though they were already sutering punsh mont. Whe reference quoted sagests bhat tothos were normally

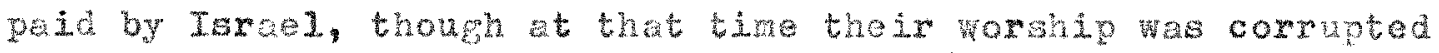
by idolatry. The exprossion "three dyst resds "three yours" In the Klng Janes Version. Hhe text hexe is elther obscuge, ox it may have bean their practice in their ldolatry to bring tithes every threo days as though such a practice would bring nerte pron God.

Second Chronicles. The great reformer Jezekiah brotiht

$$
\begin{aligned}
& 1_{1 \text { s s r pue }} 8: 10-18 \text {. } \\
& 2_{\text {Amos } 4: 4 .}
\end{aligned}
$$


the ththe into practice ebain aring the deys of his rule. Ulis

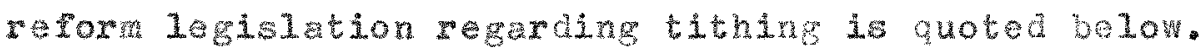

And Hezekiah appointer tho coursos

of the priests and the bevites ater their courses, every man cocoring to his service, both the priests and the Levitas, for burnt-oflerings and for peace-ofierings, to minister, and to give thanks, and to praise in the getes

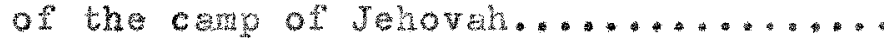
Moreover he comanded the people that dwelt in Jerusalen to bive the portion of the priests and Levites, that they might exe themselves to the law of Jehoval. And as soon as the comandment came abrod, the chilaren of Istol grve in abundance the first-prutis of gatin, new wire, and o11, and honey, and of al the incroase of the rield ard the tithe of til things broumt they in soundatiy. Ard the children of Isxael and Judata that dwelt in the citides of Judah, they also brount in the tithe of oxen and sheop, and the tithe of dedicated thinge which were consecrated unto Jehov.h their crod, and laid bhen by heavo

Hezekiak's reformeton included the reapointhent of the priasts and Levites to the law of Jehovah, to be supported by the people that dwelt in Jerusalem. As soon as the comandment was given to bxing in the priosts" and bevites' portion, the people brought In the the of all thinge abundantly. The tithe of hall things" gpecifically included that of oxen, sheep and the ththe of dedi$\operatorname{coted}$ things.

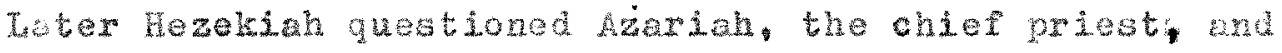
was informed that since the people hed begun co bring thejr oblem bons into the house of Jehovah that they had had plonty to ect 
and plenty was left. As a result more room was prepered to recenve the tithes. Additional workers were appointed to care for the oblations, tithes and dedicated things. God prospered Hezekiah in avery work that he started in the house of cod, and in the law and in the comandnenta. Perhaps the key to this abundance was that they brought the tithes faltherly to the house of Jehovah. There is a warked contrat between the ththers mentioned by Amos, who were engaged in idolatry, and the ththers mentioned by Hezekial who gave abundantly and whole-heartediy.

Neheriah. Nehemiah lived after the captivity of Israel and during the time of Israel's return to Jerussian. Neheniah not only attempted to restore the city of Jerusalem, but also the true worship of God. In reviving this worship he included ordinances to bring the tithes of their ground to the Levites. The Levites were to bring the tithe of the tithes unto the house of God as directed by Moses. The account of this is found in Nehemiah $10: 37,38$ quoted below.

... and that we should bring...the tithes of our ground unto the Levites; for they, the Levites, take the ththes in all the cities of our tilluge. And the priest the sor of Aaron shall be wh the tuevites, when the Levites take tithes: and the Levites shall bring up the tithe of the tithes unto the house of our God, to the chanbers, into the treacura-house.

This passace indicates that the Levites receiva the tithes in al1 bhe cities, not only at the central place of worbip.

In Nekemiah $12: 44$ it is stated that ren were appointed over the chambers for the treasures, including the tithes, to 
adrinister the poxtions appointed by law ror the priests and tewites.

Chapter thirteen relates thet flashib, the high priest, was appointed over the chamers of the house of cok. Hovever, Rlashib conmtted evil in forming an aliance with the conspixator Tobiah, who had stopped the building of the wals of Jarusa1en. Weberiah discoverea that the thes had not been given to the Levites, but rather had been e cource of gatin to Tobiah." After this discovar Wehoriah clearsed the chambers, met wth the rulers, hed the tithes brought in and appointed new treasurers so thet the Levites mint pursue their popointed task. 2 me cleanaing of the chambers by Nehomiah suggests the dignity and holiness connected with the tithes. The sanctity of the tithes was fur ther observed by the apointmont of treasurers who wers described as fathful. Whe care of the tithes by weheriah was auch as to bulld an attitude of woxship about tithing

Malachi. A near contemporary of Weheniah wes Malachi.

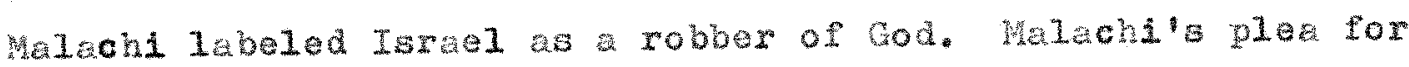
Istael. return to Jehowah is quoted below.

W11 a wan rob God? yet ye rob ne. Sut ye say, whench have we robbed thee? in tithes ata of exinge. Ye are cursed with the curse for ye rob we, even this whole netion. Jring ye the whole tithe into the storehouse, that there may be food in wy house, and prove me now herewith, acth Jehovah of hosts, If I 111 not open you

$1_{\text {Mehenian }} 3: 1,4: 7,8$.

${ }^{2}$ Malach $3: 8-10$. 
the whitow of heaven, and pour you out a blessing, that there ghall not be room enough to $x$ ecelve it. 1

The promiae of what Gou would do for them if thoy obsyed Hin in tithing continues on for two nore verses. Whis pasage employs strong terng in connection wh ththing . God extended to then

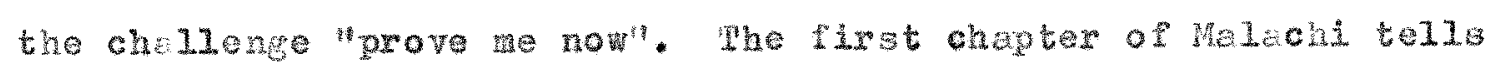
how the Israelites brought the blind, lane and ick animals for

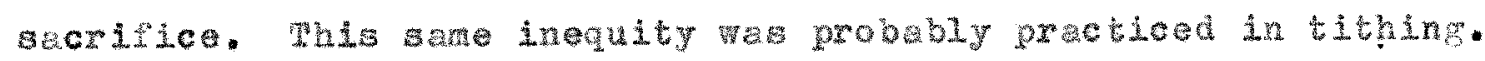
Malechl's closing words axhorted Israel to rencaber the lat of Moses which was commonded ror all reral.

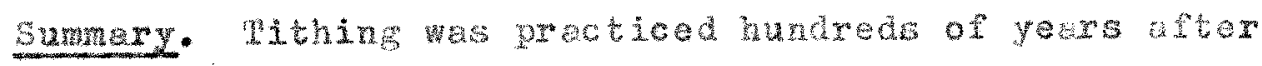

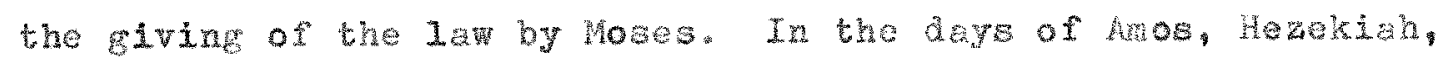
Tehomiah and Malachi corruphion often accompanda the tithing practice. Each of the leaders who mentioned tehing ald so with

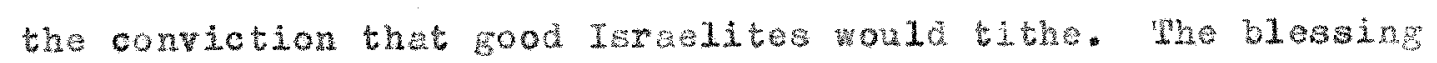
experienced by tithing in Hemektan's ay w Malachi to any who would bring the whole trthe into the storehouse.

\section{Wxtra-Biblical hepenons}

h brief study of the coments pound in somees outside the

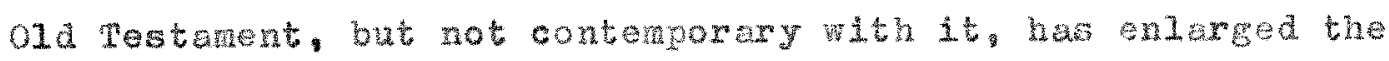
knowledge or tithang pratices durab the period of the Lav

Apocrupha. The Apocryphal books are not accepted for doc-

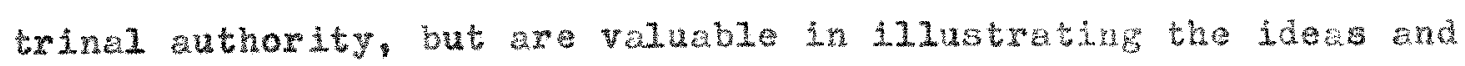

1 Malachi $3: 8-10$ 
custons of the period of which they are dochents. me book or

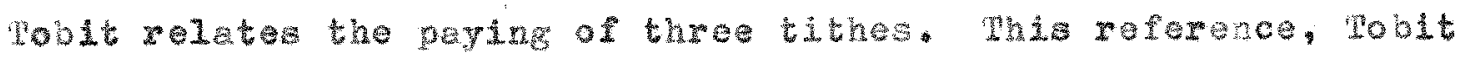
1:6-8, is quoted below.
And I alone went ofter to Jernsalen the

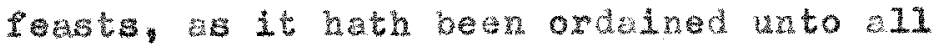
Isral by an everlasting deceo, having
the firsteruts and the terthe of mine 1n-
crease and that which was first whorn;
and I Bave then the altar to the pribets
the sons of Aaron. Whe tarth part of al1
mine increase I gave to the sona of Levi,
who minstered Jatrolom and the sec-
ond teith part I sold aray, ond weat, wnd
spent it och year at Jarusalem and the
thind I gave unto thex to whom it tow

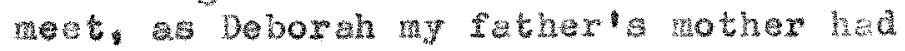
columand me becuse I was lept an orohen by my rather.

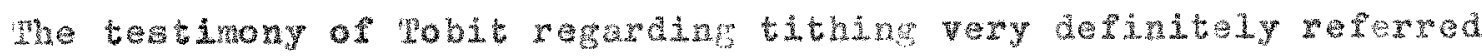

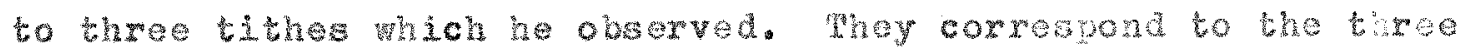

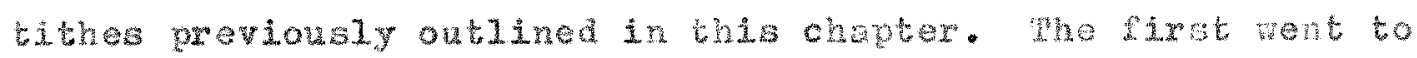

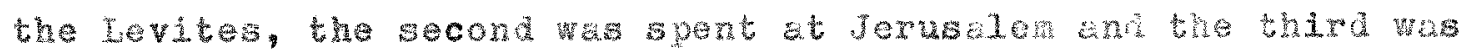

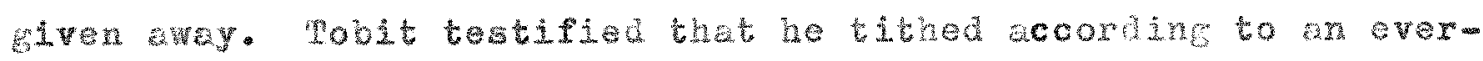
lating dectee

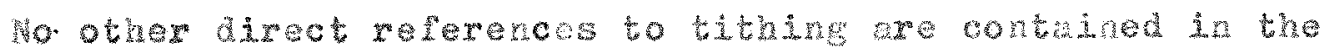

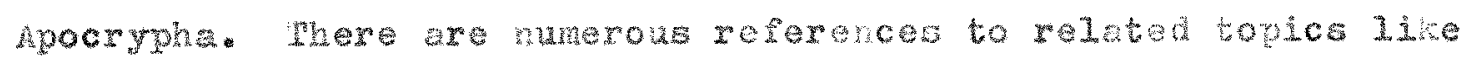

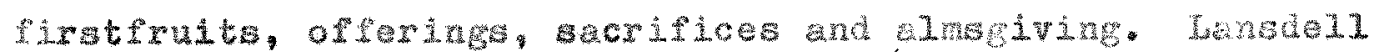
pointed out that these writings did in no wy hmoly the repeal or asuse of tithes in the three centures preceding the chrstrin ar. 1

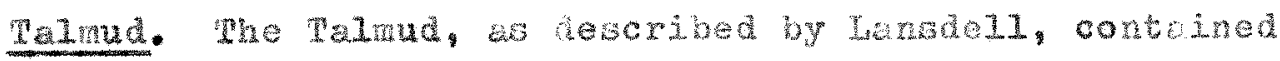

1.ansde11, op. 


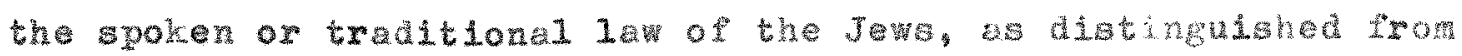

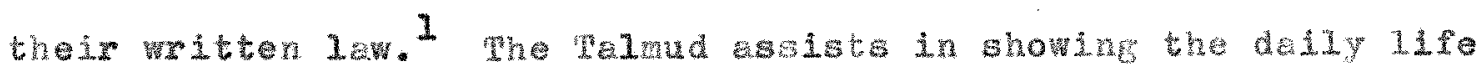

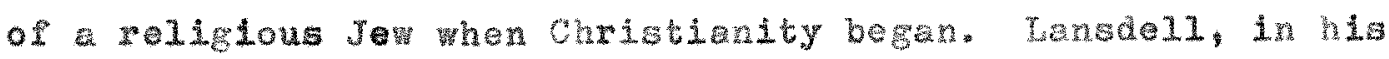

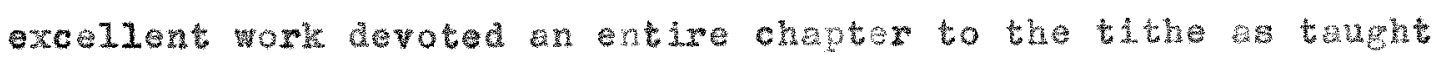

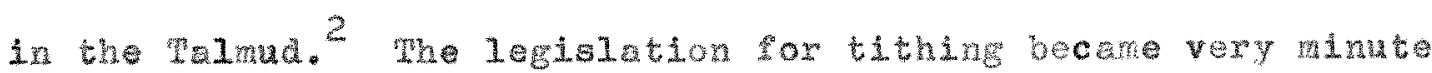

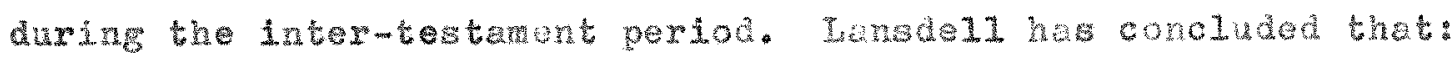

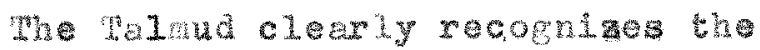
firs or Levitical tithe: the second ox festival tithe the thind or poor e tin the: and also appears to ada e fourth or suplenontery tithe of a tithe-that 10 avy of one per cent, for the priests, In cartin cases whjoh the Gentateveh let oper to doubt. 3

Some weachinge on Mithing During the Period of the lave

The Dlbichl xeferences for titing during the pariod of

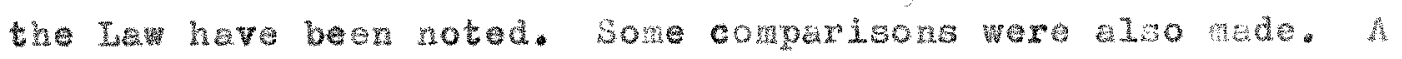
comprehenesve sulut of all these references and their contexts revaled several agrificat teachings on tithing whese teachings developed from the the logislation and practices dunge the periot of the Law.

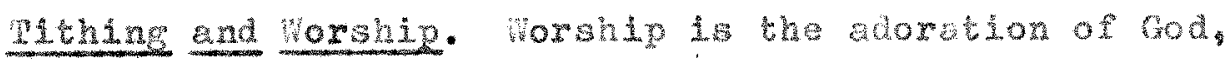
accomplishod in part by any actual mandestaton of love to IIn.

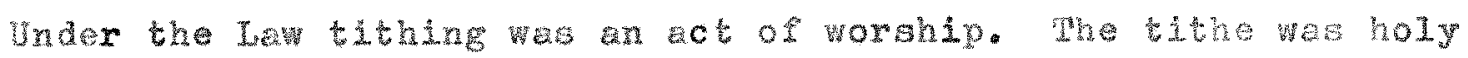

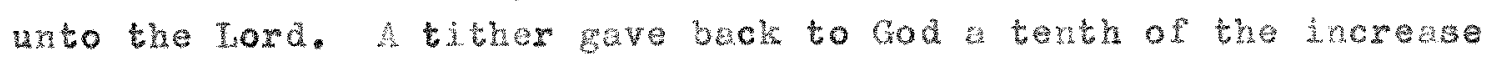

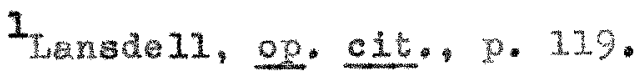

2. I1d. chaptar XII.

3 Iotd. 134.
} 


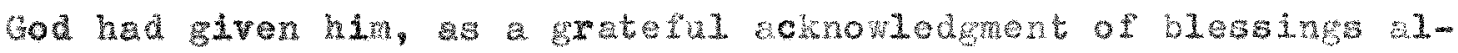

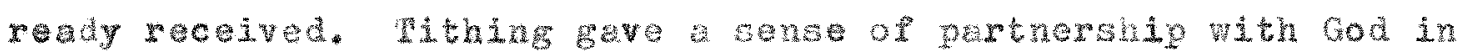

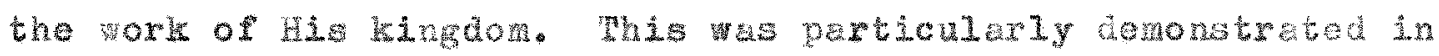
the rugort of the Levites, a

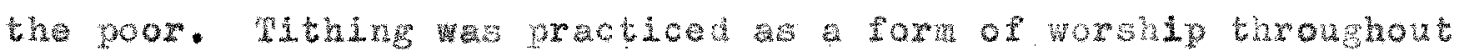
211 of Istael h history.

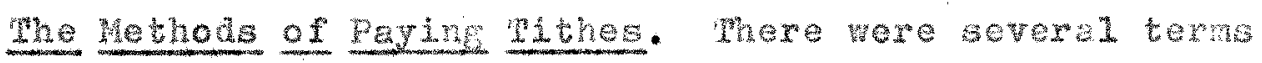
used to dosignte the place to which the thanes were brount A comaniy inow texw is that of the storchouse. other berms were: the place which Jehovah your cod and1 choose; in the plater which he ghal choose to cause his namo to dwell; chanbers in the house of Johovah: the homse of oux cod and the breasure-house. MII of these names refer to place set apart for hod muany associa-

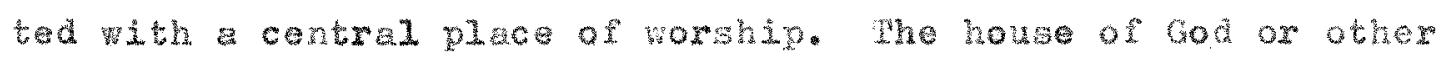

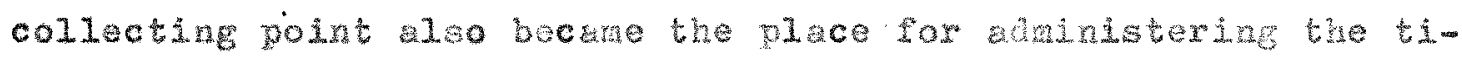

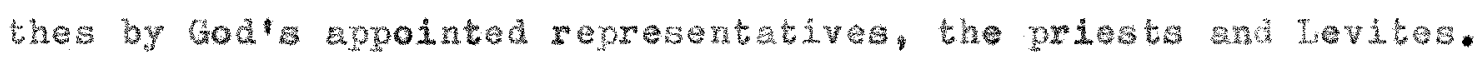
gince the tithe was holy unto the Word, It was reachable that God would brect thet the tithes be browht into his store-house. Never was the Isrelite lot lat doubt as to the place of paying His tithe. Whe Levitical tithe and the pestival tothe wore both to be taken to the cental place of morahip and the poor tithe kept at hore for tidetibution to the poor.

Whe tithes paid by the Irredites were to be more than a

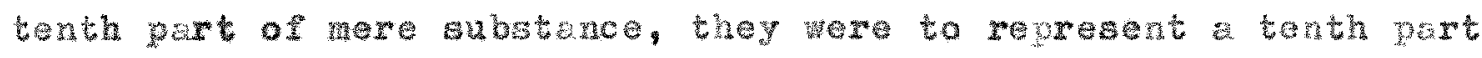
of value. The levitical tithe if redectad was to be increaved by

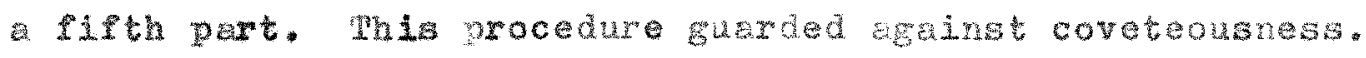


Malachi urged the people to aring the "whole" tithe into the store-house. Ihis passage would also indicate thet a tenth of value was expected. The tithe who holy unto the Lord and as buch became the acknowledgment of an obligation ratiex than the payment of an obligation. In selecting the tithe of the herd and flock the Israeltte was to take every tenth animal, whether good or bad. In the days of halachi they were bringing the lame end sick. When the Biblical instructions were followed cod recelved a tithe of value as well as a tithe din quantity. Whether the tithes represented tenth of gross or net incone was xade clear in Deuteronomy. There they were instructed to tithe the increase of the seed. Proverbs $3: 9$ says, "Honor the Lord with thy substence and with the first frults of all thine increase." This principle clarifies the computation of the tithe in any type of economy.

Uses of the withes. Hach of the three tithes were dasigned to be used for definito purposes. The first tithe, or Levitical tithe, was given to the Levites who had no inheritance in Israel. This dosignation was made as follows:

And unto the children of Levi, behold

I have glven all the tithe in Inrael for an inheritanee, in return for their service which they serve, ever the service of the tent of meting. 1

whe support of the Levites who ministered about the tent of meeting was dependent upon the faithrulness of the people to bring

$1_{\text {Numbers }} 18: 21$. 
their tithes. The Levites used their ththes an two was they

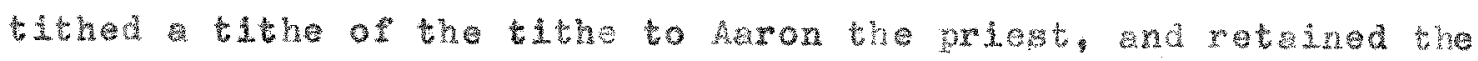

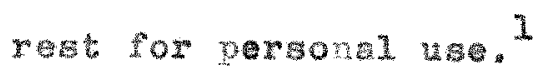

Whe second tithe, or fertivel tibno, was to be eden by the offerer, his household and the Ievita. ${ }^{2}$ mhis was a time of nejoichn befoxe God accoring to the ingtruction given them.

The third tithe, or poor tithe, was hept at the tither's home to be distributed wong the tevites, sojouners, patheriess

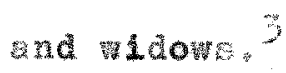

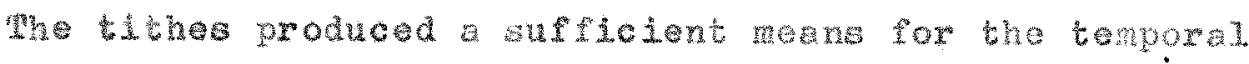
care of the priests and Jevitos. Whis wax eavecialy shown to

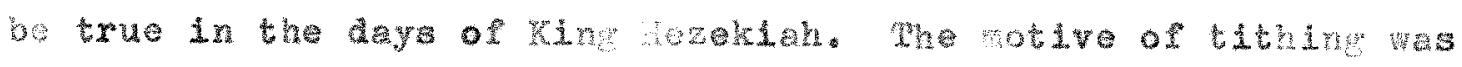

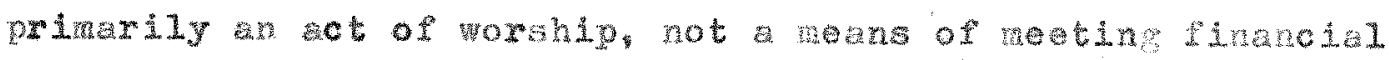

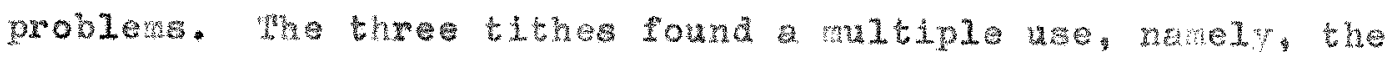

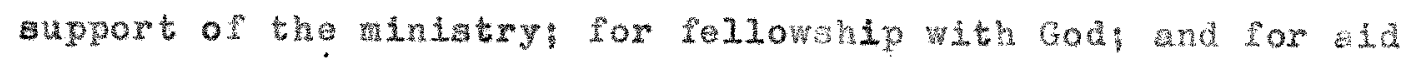
to the poor and needy.

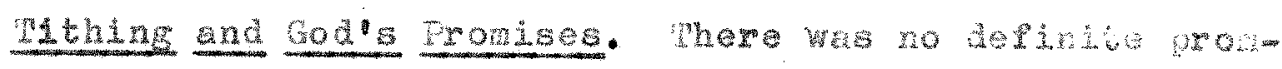

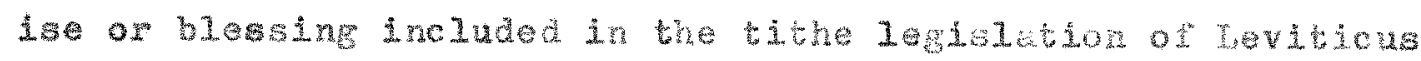

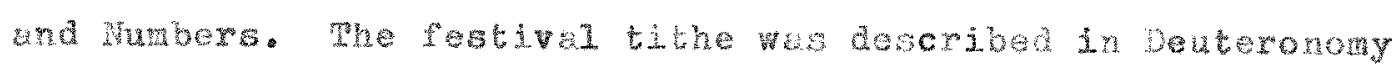

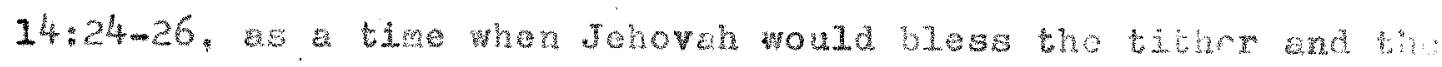

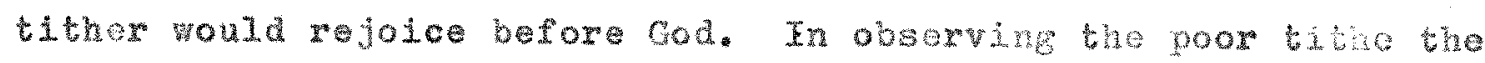

\footnotetext{
1 Wumbers $18,26-28$ quoted on pege twelve of this thesis. 2 Denteronony $14: 22-27$; qoted an peges buelve and bhixteen of this thesis. shasis.

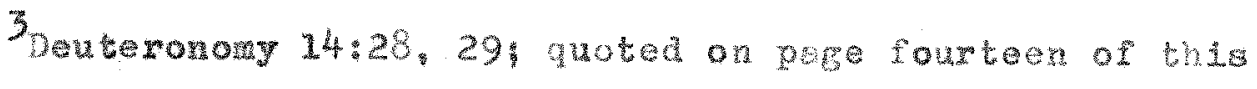


ther received the satiafaction of alding those in need and quelified to receive God's blessing on all the work of his hand.

In the days of Hezekiah the people mero blessed as a result of brimging in their tithes.?

The promise given by God through his prophet Malachi best deptcts the blessing of cod upon a tithing people. The prophet urged the nation to bring the whole tithe into the otore-nouse. God manted then to do this in order to meet the challenge of "prove me now". In turn they would discover the folloning blessing from cod.
...1 I will not open you the windows of hezven, and pour you out a blessing, that there shell not be roon enough to recelve it. And $I$ will rebuke the devourer for your sakes, and he shall not destroy the fruits of your ground neither sheld gove vine cast its frut before the time in the fleld, sath Jehoveh of hosts. Ard all nations shall call you happy; for ye shall be a delightsome Iand, aath Jeho- vah of hosts. 3

The promise of blessing from tithine was wromise of aburdance. It was both personal and national and reflected God's apecial care of thelr 1and. Pithing faithrully performed led to abundant living. rithing brought Israel a blessing, but Isxal aid not tithe solely in order to gain a blessing. The blessings lssuing apon Israel whenthing would be so extensive as to be noticed by the surrounding nations.

\footnotetext{
$1_{\text {Ibla }}$

2I Chronicles 31:8-10.

3 Halachi $3: 10-12$.
} 


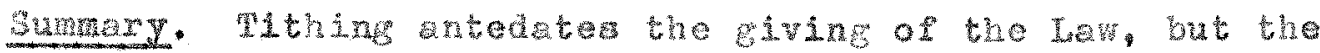
Greatest teaching and explatation of the the came during the

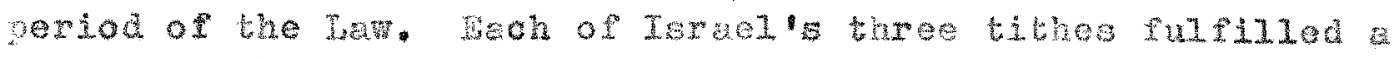
Istinct purpose. A basio princhple to the tithing pretice was that of devotion and worshp to god. Another basic poinciple was the use of tithes as a means of the financial suprox of ond Restement worship.

After examining the passages dealing wht the tithe during

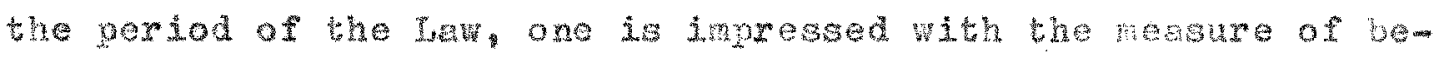
nevolence axpeted of the ancient wev. Mhere axe no Bubjoal ingtances of the Jew questioning the wroportion he was to give,

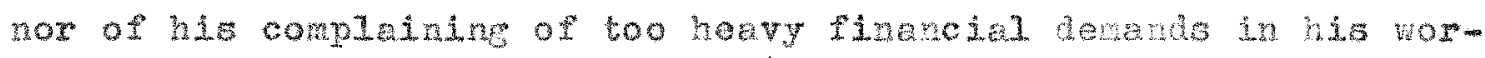
Ghip of Jehovah.

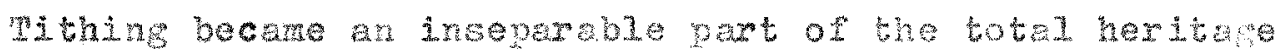

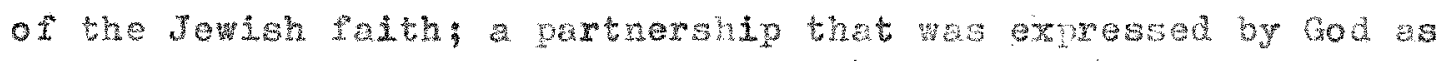
betng holy and a cource of blessing to the tither. 


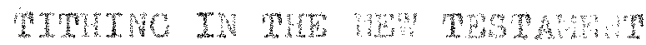

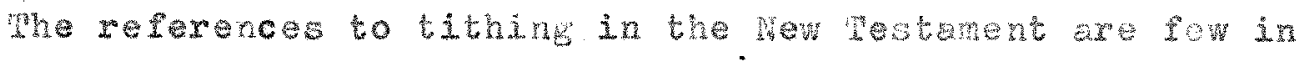

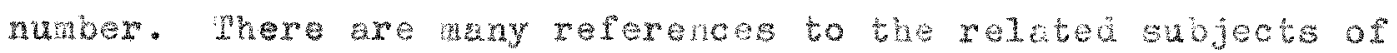
money and stewerdshp. It was conddered inporant to seek an answer as to why the titbe was not mentioned of

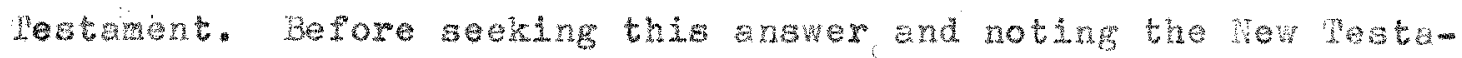
ment references a bref statement of the relationship of the old lestarant to the New Mestament is in orom.

The relationahp of the Chriatian Chuxch to the Law was

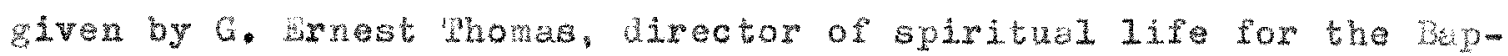

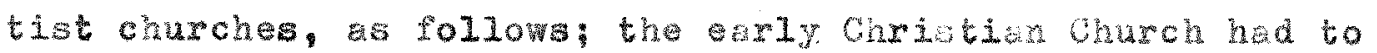
break away frow the Law in the 01 destament in order to lay clan to the allegiance of the centiles of that day. 1 At the Jerusalen Counc11, described in heta, cherter fiteon, the dpostle lat fought wh won the battle whth legalisat then proviling in the Jemish portion of the church. Ththing hed derinite abociation With the old testament Law. Thomas sald tho reason the lar was not atressed more in the orrly church was that christianity would have been greaty handicapod, and migh have eventuklly ended as an obscure sect, if falthulness to the lew rether than to the teachings of Jesus had beon made the first demand wpon the new converts to christianity. 2

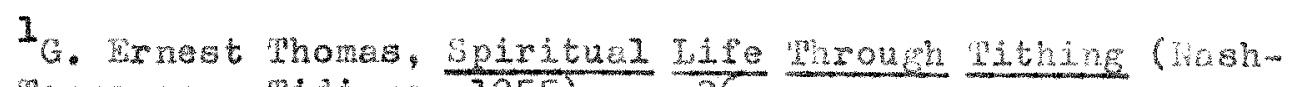
ville, Temesee, 1 idings, $\frac{1955), p}{26}$ 2 
It has aready been noted thet in the days precedinis the Christion era tithing was regarded more as a fulfiluent of meticulous commandments in the law rether than as an act of worehir. Whe task of christ and the writers of the wew gestenent was thet

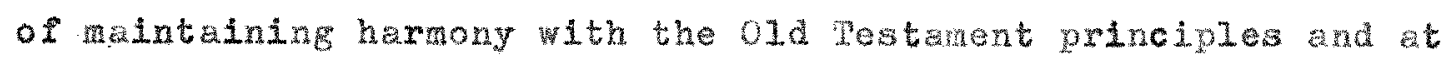
the sane tine presenting the principles of worship and devotion for Christians.

Jesus and the It the

Teachlngs by Jesus. Both the gospel of Mathew and that of Luke record the woras of Jesus to the Harisees regarding tithing. His words were a acthing rebuke to a peope who substituted legelism for spirjtuel reallty, but who also approved the practice of tithing. Mathew record quotes Jesus an Bayng:

Woe unto you, scribes and pharisecs, hypocrites! for ye tithe mint and anise and cumin, and have laft undore the weightier matters of the 1 kw, justice. and mercy, and falth but these ye oumt to have done, and not to have left the other undone.

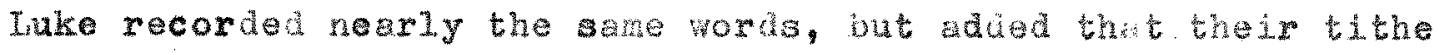
included every herb. Jesu rebuked them for neglecting justice. mercy and iajth. Whe pharisees were logaligts in tithing. with no compltment of their Iives to God.

Christ aid not eree the pharisees from the obligation to tithe. In reperence to thelr tithing he spoke ctrongly and said 
"this ought ye to heve done", mithing, as well as justice, falth and mexcy was expocted from the phardaced if they proposed to bo

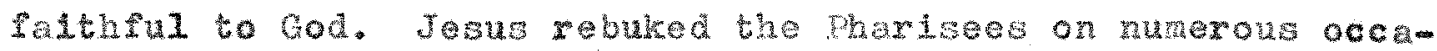

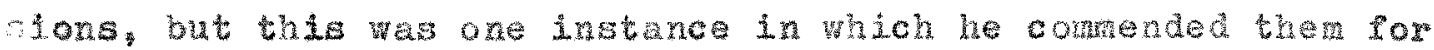
one prectice.

Jesus mentoned thing on ore other occelon. In the garable of the marisee and the publican, Jesus quoted the phar

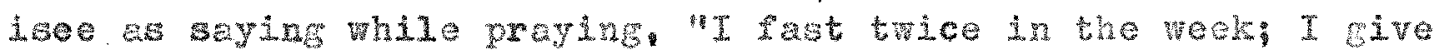

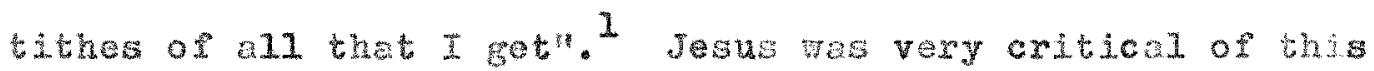

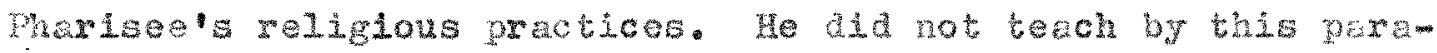
ble that ho opposed prayer, festrig, or tithing. Rather Jesus Leveled His criticism agenst the rannex of his proying and at the legalsax Implied in the habit of thing. Luke describer the audience to whor teaus adressed thin parable as bejug those

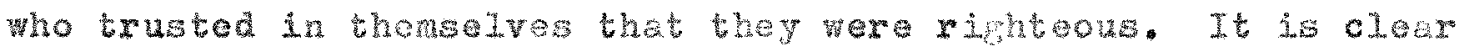
that in thes parable Jesus was not critizinge tithing, wut a wrong ettitude of attributing special nerit to the practice in company

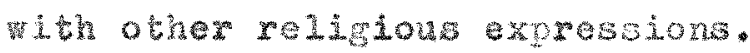

Jesus rether comanded his followers to ththe, nox did

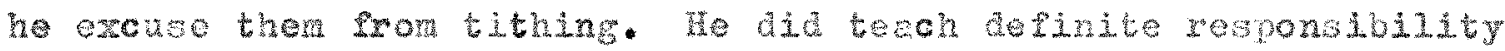

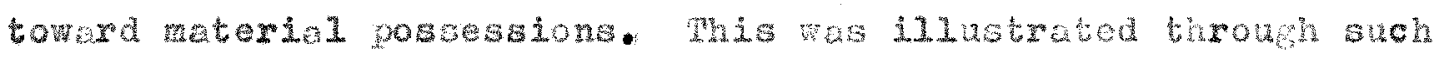

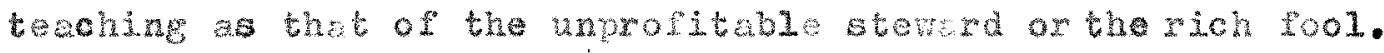
Jesus dia teach that he chme not to destroy tho s. but

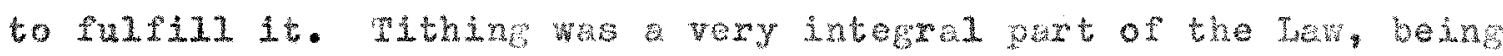


In pratice bofore the Lew. The teachirgs of Jesus about tithing wexe adoressed to those Iiving under the Lew. Jesus' concept of the herding of matorial possesions was so extensite as to make

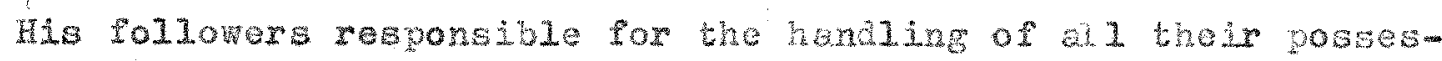
sions, not just athinglness over a tenth.

There is another incident recorded by Mathey wich ctrong ly imples that Jesus believed in tithin. 1 The harkses conironted Jesus with the auestion of poynd tribute to the Romans.

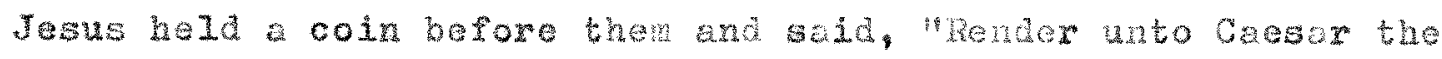

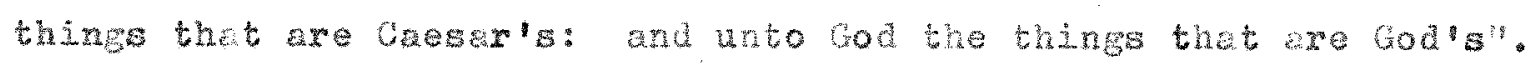

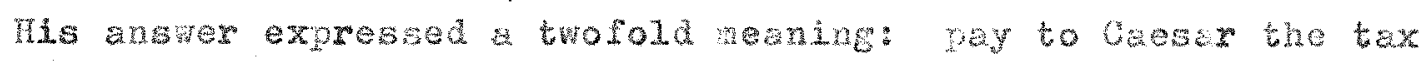

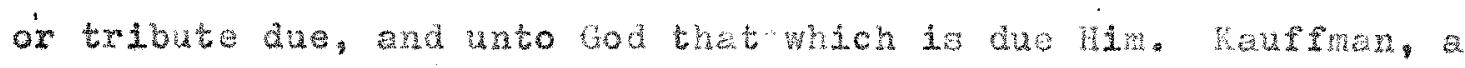
Fennonite eductor ard aubor believes that the Jews inth their

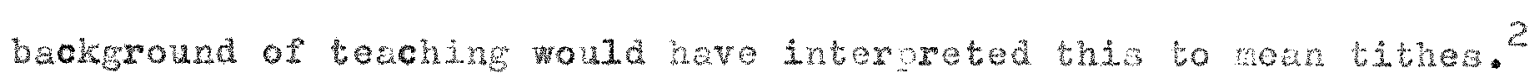

mo beachings of Jesus on tithing were very brief, but were clear in indicking that tithing was expocted of those Iiving undex the 01d westement Dew

Jesus and stewerdshin. stewardship as usea in this thesis

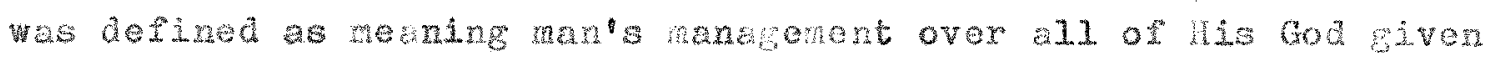

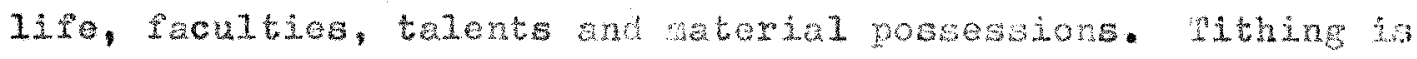
one aspect of the broader subject of stewardship. The teschings of Jesus concerning tho more general subject of stewndsh were considerod as a directive os his attitude toverd tithing. Money

\section{Wathew $22: 17-21$.}

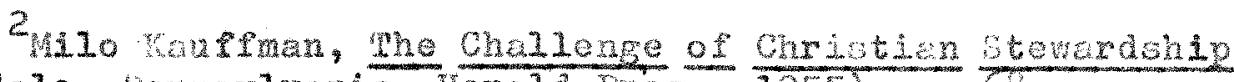

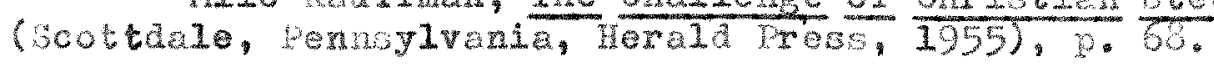


is rrequenty mentioned in the new restanent. Jesus often related the dangers of money and possestions to the splritual 1 ife and we11 being of the soul. On one oceasion Jesus said, "How hardy shall they that have riches enter into the lingdom of God". I In Matthew, chapter twenty-five, Jesus declared a severe penalty upon the unfeithful steward. Jesus described the mon that laid up treasures for himself as not being rich towerd God. ${ }^{2}$ In his observations of the widow who gave her two mites, Jesus teatified that she gave more than 11 the othors, in that she gete her all. 3 By so doine Jesus stressed the value of propoxtion in giving rather than stressing guantity. The guanity brought by the widow was very small, but the proportion in her caoe represented her all. Jesus aleo baukt that it was nore blessed to give than to receive. Thomas related Christian stewardship to tithing and said

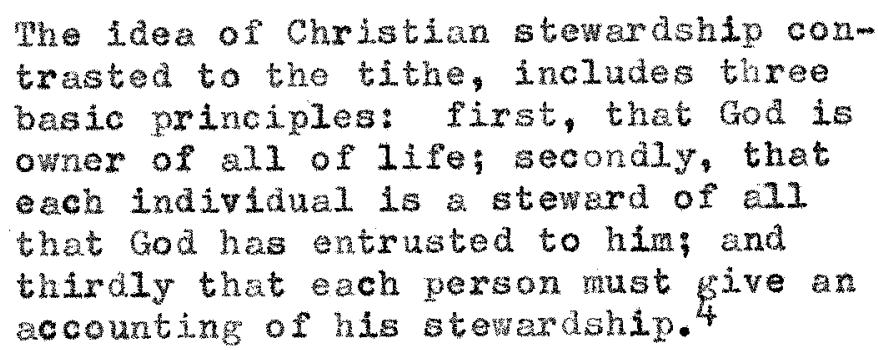

Whe teachnge of Jesus on stewardshlp placed a very vital relationship between the individulis life and his possessions.

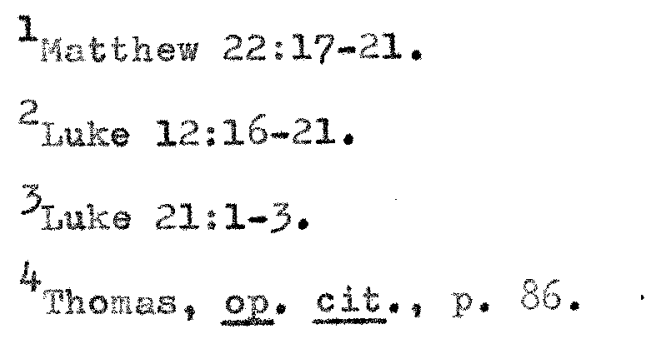




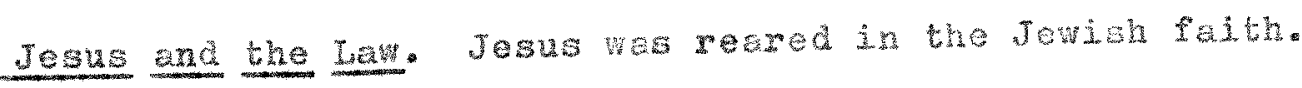

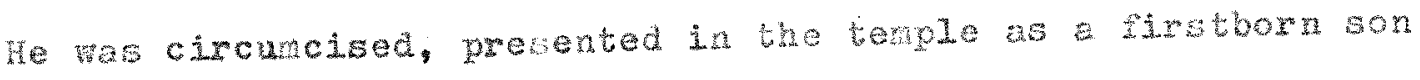

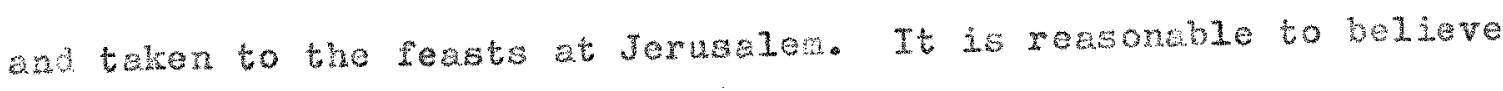

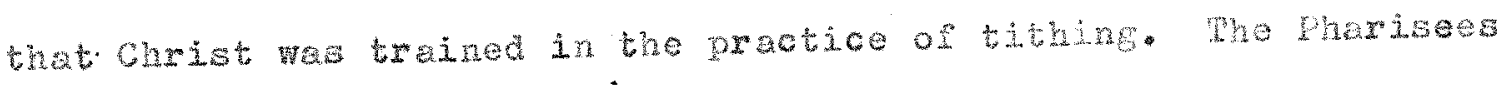
trad in warious suble wys to accuse jesuc, but they never are recorded tes having charged him with violating the principle of the tithe. The life and teaching of christ in no way ever contraacted the tithe practices.

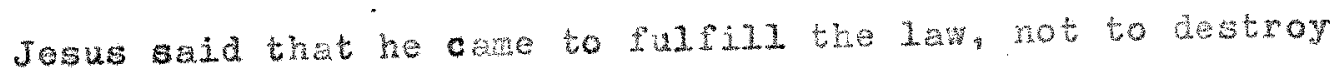
1t. I The Jewhsh 1 aws were of throe types: moxal, cerenonial and civil. Which of these aid Jesus refer to? It is quite eivant that the civil and cerenoniel laws underweat arstic chenges ju the tranition to the christian folth. Whe moral lav of wod is wnohangirg. Withing originated berore the ingtitution of the cerononid Jewtoh laws. It was later inclided as part of whe

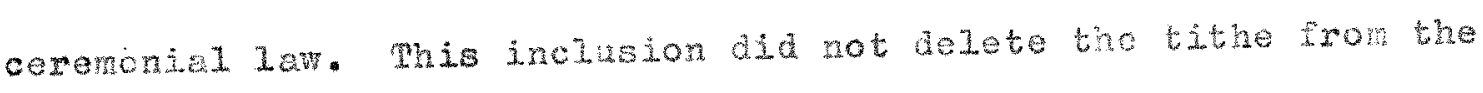
moral law to which it first belomged as an act of worshis me ceremonial laws were prinexily intemced for the Jews but the noral Iaw continues binaing upon christians. Me pherisees diligentiy practiced tithing, but Jesus also sald that except the righteons ness of his followers excepded the of the phrisces they would not enter the kingdor of herra. ${ }^{2}$ whe tithe was in no way abro-

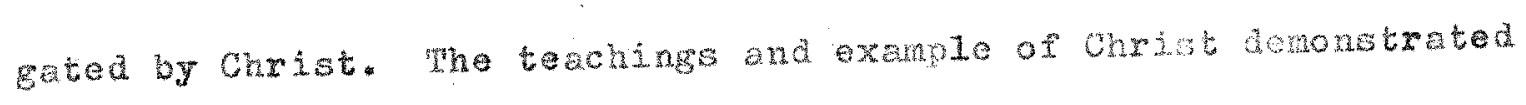
hicher principles than those contaned in civil and ceremonicl low.

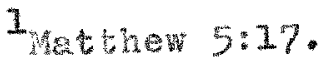

entather $5: 20$.
} 
pal and athing

parl never made a drect reference to bithing undess the

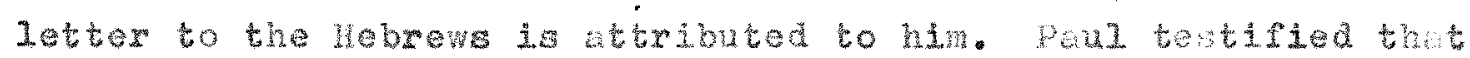

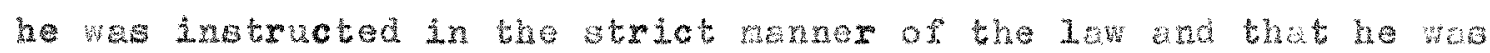

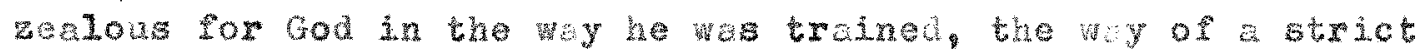

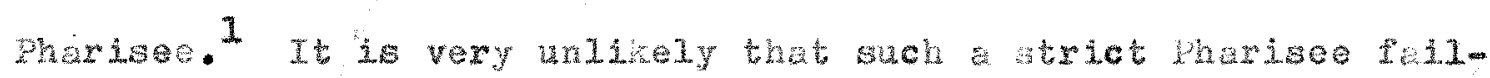
ed to tithe his incone before his conversion. Mo emphais that

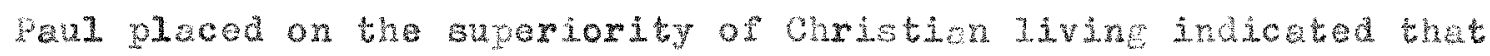

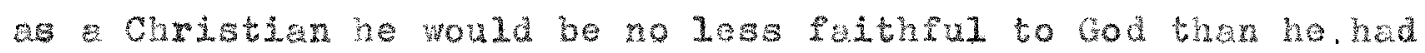
been as Jew.

Paul, in his eirst lettor to the Corinthin church, taught proportionate giving. He triote,

Wow concening the collection for the solnts, as I gave orcer to the churches of Galatia, 50 also do ye. Hor the rists day of the week 1 at each one of you 1 ay by han in store, as he may roosper that no collections be mede when I come.

proportion la sugested by the worda, "ta he may prosper". Whis sugestion to the eary church no doubt reminded ther of the

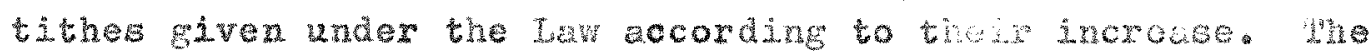
church at Corinth to whom the apostle paul wrote those words hal

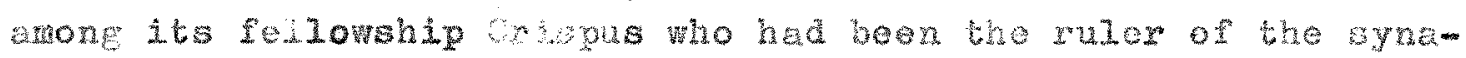
gogue at Corinth. Crispus, with his Jewish pest and position, must have been familiar inth the Jewish tithe. That these words

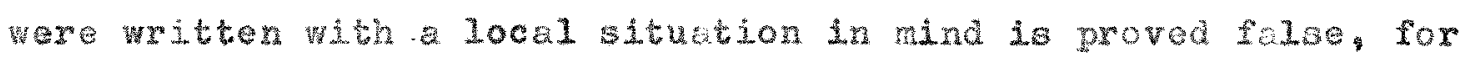

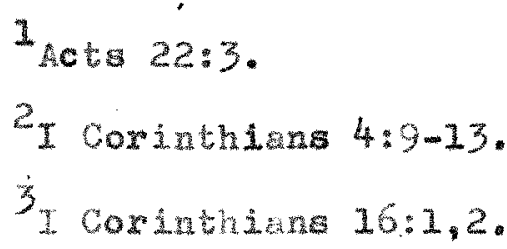


Paul says that the instructions were the sche as he bad fiven to the chunches of Gelatia. Galatia was hundxess of miles distant Iron Corinth and the site of at least three well cstablithed churehes.

Mis passage not only teaches proportion, but inks to it other instructions for receiving the collection. The collection was to be received regularly, on the firet day of the ween. It was also to be regarded as an Individual responsiblity as buggested by the words "each one of you". Syatem was taugh by the instruction to "1ay by him in store". Phis laying by necessitated consecration to the task. The collection paul wrote about was for a particular need, that or the Jerusalem aims, but that does not detract from the points in the procedure for the collection.

Pal's second letter to the Corinthian Church ahorted the church to abouad in the grace of liberality, in the same menner as the churches of Macodonia, who had proved thencelves 13 beral even in the ridst of poverty. 1 mis pessege also points out that this kind of aboundang giving was to prove the sisersty of your Love". This was the New Pestanent staudar of Christian giving. In the ame Jetter panl told the Corinthing that cod loved a cheertul giver.

In the old Testatent the priests and Levites who ninistered in the temple received tithes from the people. After referring to this custom paul reminded the Cormbinans the the lord hed

\footnotetext{
$1_{\text {II corinthians } 8: 1-7}$

${ }^{2}$ II Corinthians $9: 7$.
} 
oxdained that those who preach the gosgel bhould live of the gospe1. 1 mis necessitated sore type of support from the christians. Raul drew a paralel between the weviteg and those who preched the gospe1. The inference of his staterient was that the Levites had received tithes and that the christian minstroy should be supported in a sinilar manner.

Paul woh his Jewish backgrourd and zealous activities as a lariaee was undoubtedy familax with tithing. His silence on the subjoct does not indicate its unimportanee to hin. Wis teachings on giving and scoriflce wtuess to a philosophy of fivirg which auggests a atandard equal to the tithe he knew as an andent young Jew.

Mhe roistio to the mebrews

gre account or Abrap peying tithe to Melchizedek the priest occkre in the book of cenesis and was discussed in chepter two of this thesis. The writer of liebrews brings the account to further polnt of discusston. The early chapters of Hebrews show Jesus to be grater than the angels, and greater than tho great Jewish leader Hoses. Je Jus was wade a high priest forever. after the order of Melchizedek, The writer points out that christ was greater than the Levitical priesthood. The exiaterce of a priesthood outside the ranks of the Jevitical priesthood is perhape the wan theme of chapter six and seven.

\footnotetext{
I Corinthins $9: 13,14$.

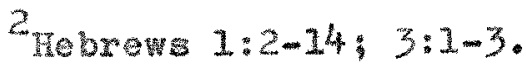


Melchizedek rocelvad thos from foraham and the incident

1 a descibed as follows.

For this Melenizedek. Who met Abra-

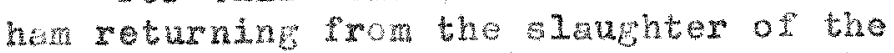
kings and blessed hin, to whom also hbraham divided a terth part of ald boing irst, by interorettion, King of $x$ ighteousress, knd then elso ring of salom..." without ather, without mothar, whout genealogy, having neither beginaine of

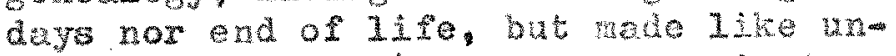
to the son of (God), abiden a piest continualy. Now consider hov great this max was unto whom Abrahan, the petraxch, Gave a tenth out or the chier spolls. And they indeed of the sons of levi that recelve the priests office have commandmont to take tithes of the people according to the law, that is, of their brethren; though these have come out of the loins of Abrahan: but he whose cenealogy is not counted from them hath taken tithes of Abraham, and hath blessed him that hath the promises. But whout any dispute the less is blessed of the better. And here men that die receive tithes: but there one of whom it is withessed thet he 1.veth. Mnd, so to say, through horehat even Levi, who receiveth tithes, hath peid tithes: for he was yot in the loins of his father, when Helchizeder ret him.

The prinary emphasis in this passuge is the relative superionity of Christ over Levi and Melohizedek. The way in which this superiority was expressed was through the titude. Even the wevites who received ththes were in the Lins of Abranch whon he paid the tithe, and therefore may be sald to huve peid tibus to Melchizedek. The men of the tevitical priesthood who received bihes were men who died; such was not the case with Melchizedek or christ.

$1_{\text {Hebrews }} 7: 1-10$. 
A1 those who worshipped Jehovah in the old Iestament were to tithe. Wwen the Levites tithed the tithes they received as their income. Those to whon the letter of the Hebrews was addressed worshipped Jesus Christ, a priest of a higher order. A logical inference is that worshippera of christ should render an acknowledgment of God's ownership in as great measure as did Abrahan, Jacob and the Israelites.

Tithing was begun before the Mosiac Law ever came into existence. It was later incorporated into the law and elaborated upon. Whether or not the practice of tithing belongs to the period of the Law or that of faith has been answered by Dr. D. She1by Corlett, a Nazarene author, as follows:

Tithing belongs to the realn of faith, Abraham, "the father of all them that believe" (Rom. 4:11) paid tithos to Melohizedek, the priest of the Most High Cod over four hundred years before the law was given by Moses. The law gave explicit command far the observance of the practice of tithing in Israel, for by law they wer required to do what Abrahan did by faith four hundred years before; and they that received the law paid tithes in Abram, (Heb, 7:5-9). The critstians are children of Abrahar, "They which are of fatth, the sane are the children of Abrahan... Bo then they which be of faith are blessed with faithful Abraham" (Gal. 3:?,9).1

\section{Sumary}

The New destament reports two occasions when Jesus of Nazereth mentioned tithing. Both of these references were

1). Shelby corlett, 480 ie of Btewerciship (Wansas city, Mo., Beecon Hi11 eress, $1950 \%, \frac{1}{35}$. 
adresser to those Living under the Law In each op these in

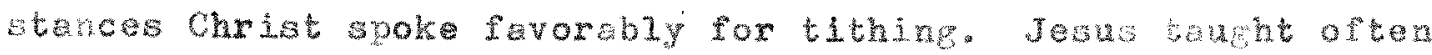
concerning money and possessions. In this teaching he buxht against coveteousness and stated that it was nore biessen to give then to receive.

Paul never made any direct reconencos to tithing but his strict Jewlsh bookground levved Ittle houbt as to his knowledge and pratice of tithing as a Jew. pau did tach the churehes to take collections and to give proportonately as they had mosm pered.

The Wistle to the debrevs depicts Chriet as priest of a greater ordex than thet of the Levited. Bven as doxthem gave a tenth to Malchiredex, so the wevites whlo sill in fbrandms Iolns paid thes to kelchizedek, Christ, wiest forever ef ter the order of Melchizedek would be entitled to recolve tithes from those who worship Hin.

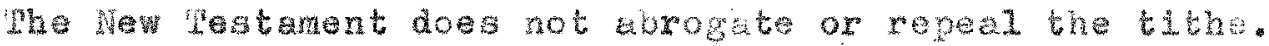
Jesus came to fulinl the Law, but this action did not destroy the how L Law. One aspect of the Horal Law wes an ackrowledgrent of God"s ownership through tithing. Ithing had its origin bejore

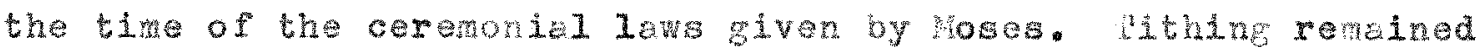
as a mean of worship in the dey of our word, the tithe continued to be holy unto the Lord. 


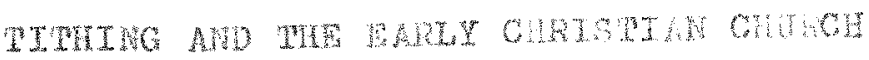

Ine attutudes and luterotetations of the exrly christian

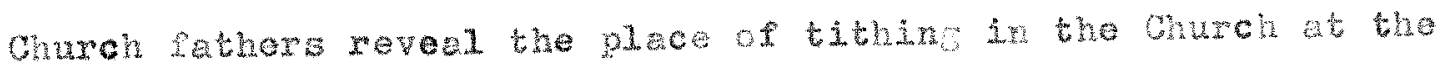

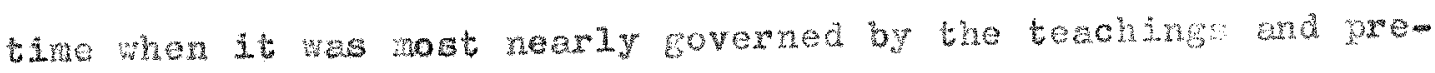

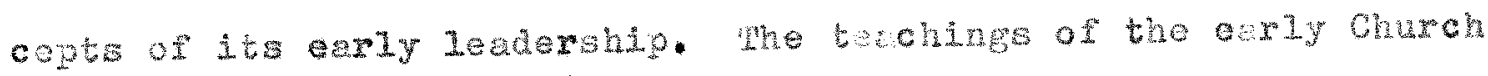

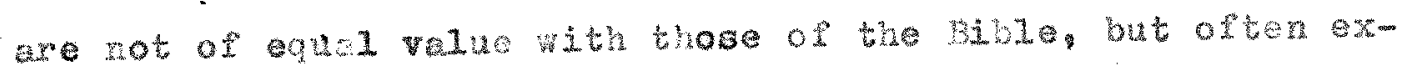

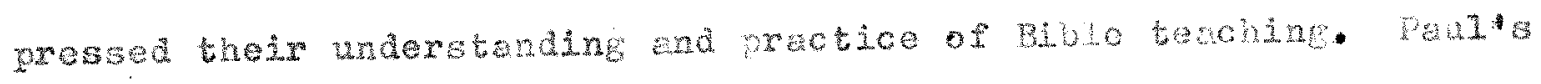

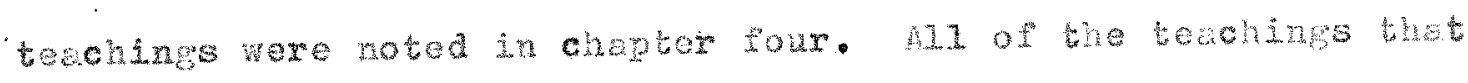

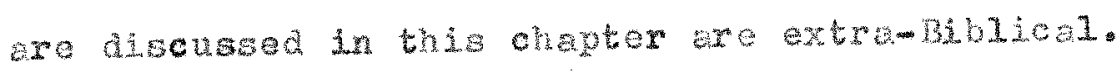

\section{Church rathers}

Ireneeus (A.D. 120-202), stuaied in Asis Mnor whin a hundred yeus of the days of the hpostes. he bockne Bishon of

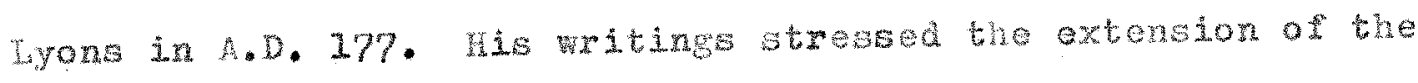
sasw by Christ, as pollows:

$$
\begin{aligned}
& \text { we precept of the pextect } 1 \text { to dre the } \\
& \text { sane in each testament... The ford abd not } \\
& \text { abogate the } 1 \text { wo whoh also those who ace } \\
& \text { justified by tath did observe, movions } \\
& \text { to the giving of the law, but extoncted } \\
& \text { then. } 1
\end{aligned}
$$

As an examplo of this extendion of the lat Ironcous mentioned

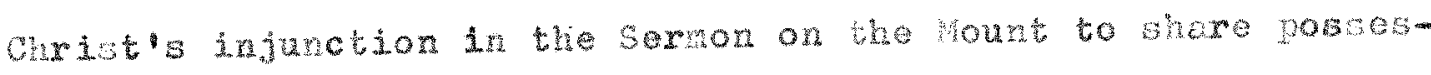
sions wh the poor. Irenceus contrusted the servitude of the

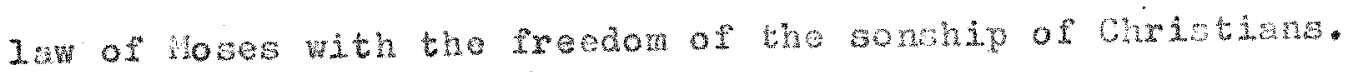

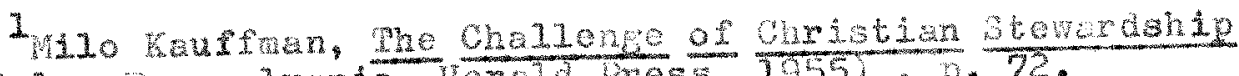

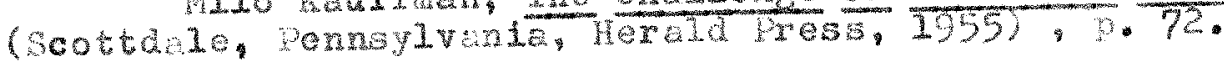


Whe contrast is quoted below.

And for this respon whist they

(the Jews) used to oomsinder the ththos

of their property as consecrated, they"

on the contrary, who have arpehended

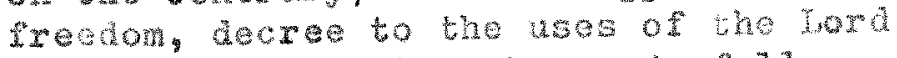

21 things which they have joytuldy

ard treely giving not what is less, 1

intach as thay have a reater hope.

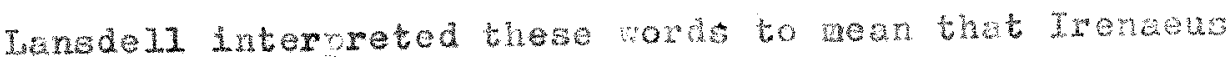

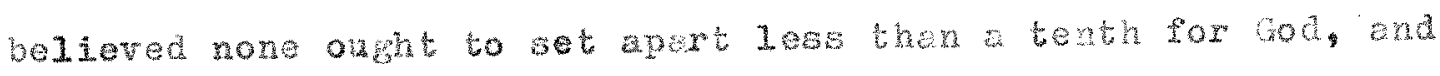

that those who would go to the highest point of duty ought to

dodictite all they possess. 2

Clement of Mlexandra (A. D. $153-217)$, decussed the source

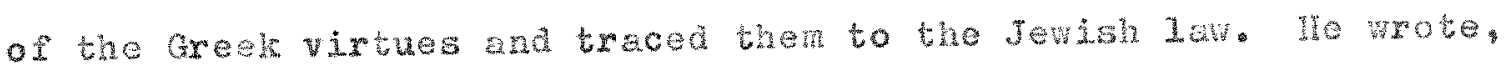

Besides, tha tither of the frults and of

the flocks taugh hoth piety toward the

Deity, and not covetousiy to grasp evexy-

thing but to conduntate giftos or kind-

ness bo one" nelghbors. For at was

these I rom,ion, and Prom the first-frutts

that the uriests were nantaned. We now

therefore understend thet we sre instruc-

ted in plety, and in liberality, and in

Justice, and in hamanity by the 1 an. 3

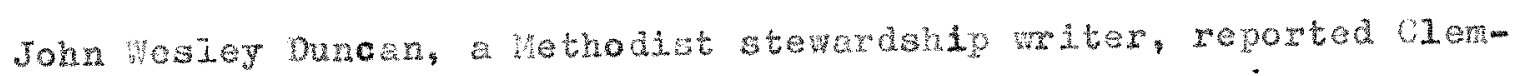
ent to have araerted that the Mosate law concaming tishes was binding upon Christians that worship and tithos bo togethor.

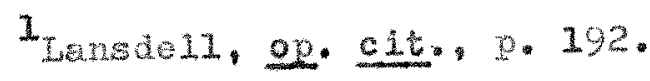

2.19.

3. D. Stewart, The The chicago, Mlonois, The wirone publishing Company, 1903), pp. 18, 19.

${ }^{4}$ John Wesiey Duncan, our Christien Stewordship (Cincinnti, Jennings and Grohem, 1909), $\bar{p} .62$. 
Origex (A. D. 185-253), was a aisciple of Clement. Oxtgen commented on Jesue' words to the Pharisees when he conmended their tithing but rebuked then for neglecting the weightier mattere of the law, by saying:

Notice more alifigenty, therefore, how the word of the Lord would by 211 means have the greater things of the law done, but not so that these things which are intended to stand according to the lotter be onitted. 1

origen knew that some would say thet these words were addressed to the pharisees and not to the disciples, so he reminded then of Jesus mords when he said,

But if you say, this he said to the Pharisees, not to his disciples, hear Hinm self again saying to His disciples, Mxcept your $x$ ighteousness shall exceed that of the Scribes and Tharisees, ye shall not enter into the kingdom of heaven'. What therefore He would have done by the fuarisees, wuch more, and wh greater tabundence, would he have fulfilled oy his disejpies.2

It Is seen then that origen's conviction was that the disciples were to the.

Gyprian (A. D. 200-258), was a Bishop of Carthage. On one occasion Cyprian mrote to dissuade a presbyter from eccepting the postition of guardian, saying:

The tribe of Levi had no inheritance, but was supported by tithes, that they might devote thenselves entirely to divine service... which resoning and form is not

$1_{\text {Lansde11, op. cit. }}$ p. 183.

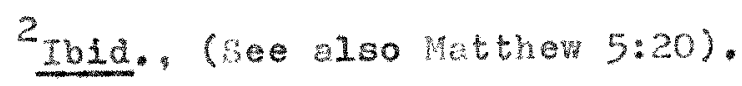




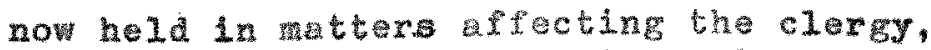
that those who are promoted by clerlcal ordination ln the Lord's church should on no account bo called avy from these Divine duties. . but...recelving rom the aldar as it wore, tithes ixom the fruit of the earth...should not go back. 1

cyorits in has treatise "on the Unity of the Charch" doacribed the Church's weakered condition due in pert to a talume to tithe. In this work he wrote

But in us the unaninty is dininshed in proportion as liberality of morking is decayed. Then they used to give for sele houses and estates and thet they wht lay up for theraelves treasures in herven.. but now we do not even give whe tenthe from our petalnony ant whe on Lord bids us seli, we rather buy wnd increase our store. Thus has the visor of falth dwinded and from anong ue thus 2 has the strength of believers prown weak.

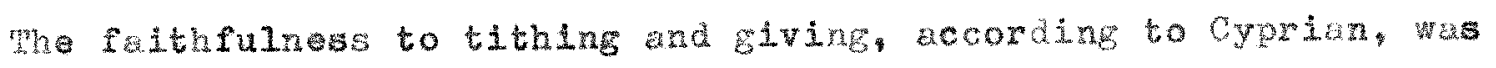

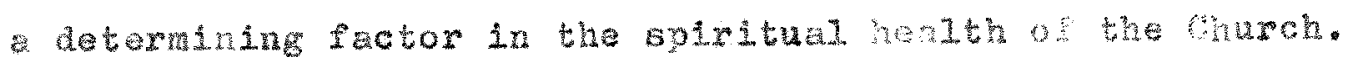

Jerome (A. D. 345-420), was an eariy Bible traglabar. In his commentary on walachi, chapter three, he wrote:

What we have said of tithes and fixstruits given by the people of old. to the priesta and Ievites, understand yo liso for the people of the church to whor it is commanded not only to

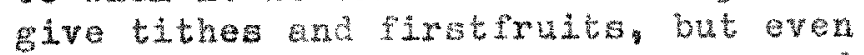
to sell al and give to the poor and rollow the $x$ ford and saviour which if we are uniling to do, at least let us imitate the examples of the Jews. so that we may give a part of the whole to the poor, and pay due honous to the

I George A. B. Salstrand, The Ithe (Beyer Book louge. 1952), .40 .

2stewart, op. cit. p. 21 . 
priests, and Levites...If any one shall not do this, he $1 \mathrm{~s}$ convicted of defradIng and applentsing God. 1

Jerone constered the tithe binding on the church, but the the ad not represent late exough proportion in relation to the noeds of the church. He spoke etromely or the guth of any one who did not 1 ifye up to the stander of tithing.

Mmbrose (A. D. 340-397), was elected Bithop of Mlan about

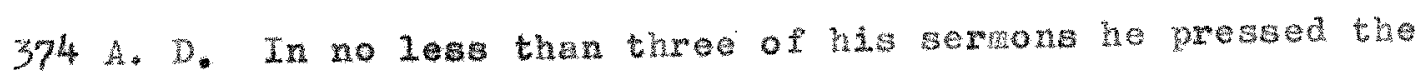

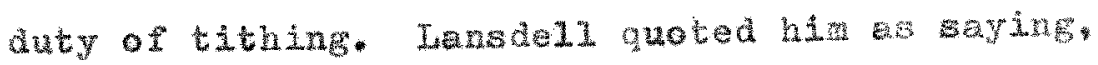

I It is not enough that we bear the name, if we do not the worcs, of chrsistians and the Word hath comanded the the tithe of all our trutis, cat 1 , eto. (be annualy requlred). It ls also written, "aive bithes of all your Iabours, etc." (after which he guotes Deuteronomy, chapter fourteen)...the nine paxts ax given you but if you w11 not give cenths, you biald be rew duced to tenth.

In a discourse on repertance he spoke very strongly whon

he $1 \mathrm{~d}$

Mosoever allows hincell to not falthiluy pay his tithes. it only we-

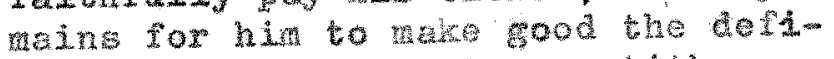
ciency. What is it to pay thes

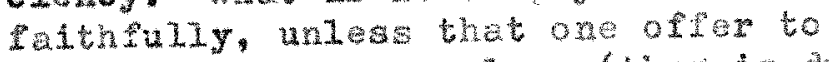
Cod weither more nox 1 ess (then $1 \mathrm{~s}$ dub)

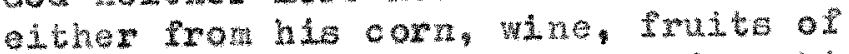
trees, cattle, or erom his gexden, his buglnesa, or cven from his huting? of all the substance which God gives a men, we has reserved the benth pat

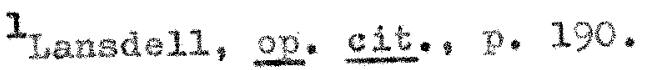

Ibid., p. 188.
} 


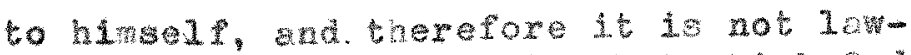
ful for a war to whbhold that which cod

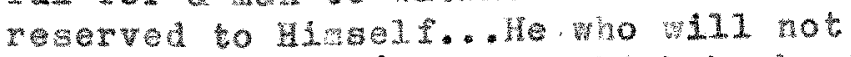
render to Gol the tithes which he kapt beck, and is not zealous to render wheto

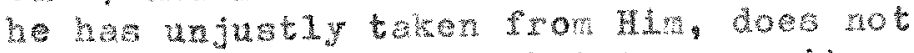
yet Sear lod, ox snow wat true ponitience

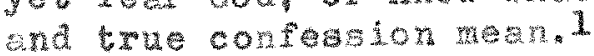

Mbroce did not believe thet true repentence was axhbited if a

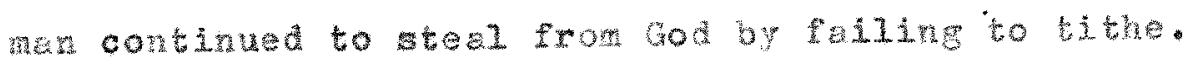

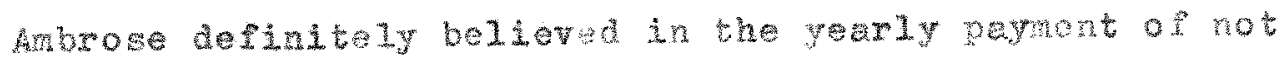

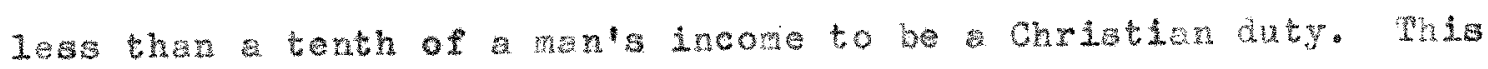
was evident from the allowng portion of a sermon preached on Ascencion Day.

He is really good christian who does not taste of his fruits berore he has offered to cod something from them who ronder to God, yox by, year, tithes to be expender on the poor. 2

Excerpts from the life of Ambrose indicte that he prac-

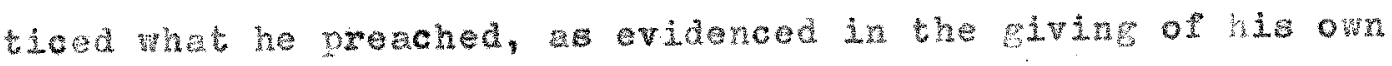
posasessions.

Augustine (A. D. $354-430$ ), was a Busop of Hivpo. Aubusthe gave an entire discourse on tithing su whoh he began by sayng these words:

By the grace of Christ the dey le now at hand, in which we onght to gether the harvest, snu, therefore, should be thinking about returning thanks to cod who gave 1 , both in the watar of wexing offering and readering our tithes.

\footnotetext{
1 Isasde11, op. elt, op. 188, 189. 2IbId, 0.189 .
} 
Pox our god who has designod to give tho whole has condescended to seek back from us the tithe, doubtless for our profit, not $\mathrm{w}^{\mathrm{a}} \mathrm{s}$ own. 1

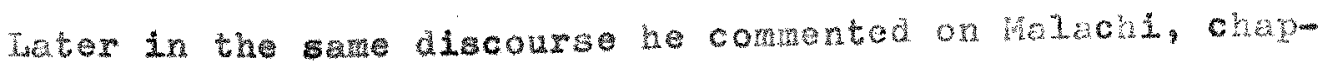
ter threc verse ton and other scriptures and said

For tithes are the tribute of needy souls. Render therefore tribute to the poor: present offerings to the priests. 倘at

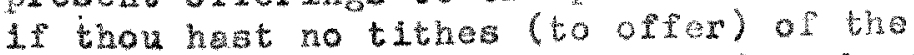
frults of the earth, Es a Musbardxan kas? Whetever talents feed you, is of cod, and he expects tithes from what you 1 ive by: from warefe, from business, from handicralt...8ince, then, by tithe-Eving you are promised both earthly and heavenly rewards, why should you by a couble ava$x$ ice defrad yourself of blessing?

Wear the and of this grest discourse he added:

For tithes are reaured as a mater of debt, and he who has ben unwling to give thon has beon guilty of robbery... whosoever, therefore, either desires to secure reward tor hinself or to bo promm ised remission of his sins, 1 st min rencier thes and out of the nine parts let hin seek to give alns, so, whitsoever mas rem waln from those same nine parts ater nom viaing noderate diet and $x$ ational cloth1.ng, be not reserved for luxury, but be placed in the heavenly treasury by way of alns to the poos. 3

In Augustine's day the Worthern horders were invering horth Afica, and he did not hesitute to conmect this scounge and the excesive texation laid upon then to their neglect of tithing. Wh words 50110 w:

$$
\begin{aligned}
& \text { I wasdel1, op. cit.p. } 185 . \\
& \text { 2rid. pp. 185.186. } \\
& 3 \text { Ibid. p. } 186 .
\end{aligned}
$$


Our forefathars abounded 1 m platy becruse they bave to God tithes and to Caesar tribute: but now, beckuse our devotion cowards God has recedod the inposition of taxes bas advanced. We

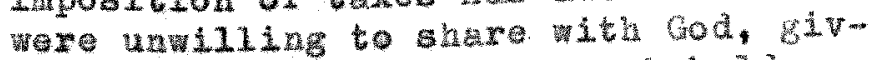
Ing Hin the tenth, and now, behold, the whole is taken from wa. whe taxgatherer takes from us that which Christ rectives not. 1

Augustine in a coment on whe words of Jesus to the than-

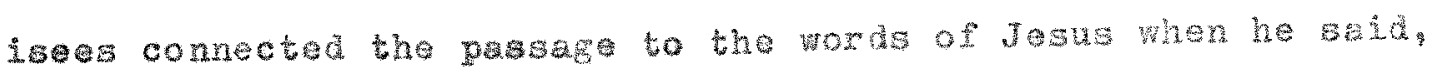
nincept your rishteousmess abound wore than that of the scribes

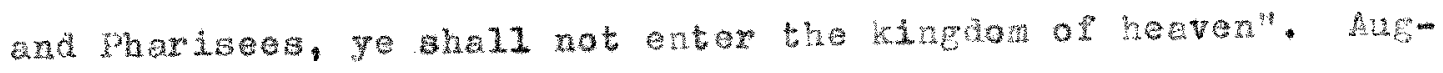

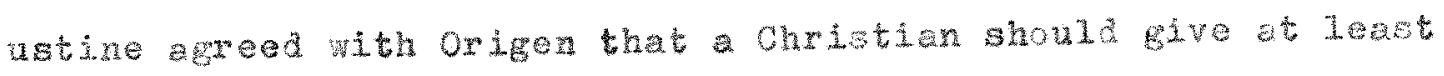

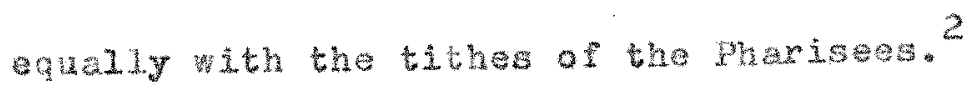

John Chxysostom (A. D. 347-407), wepresenta the wastern

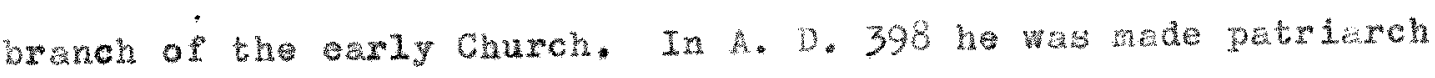
of Constantinopla

In a sermon on Geneala, chapter twenty-eight, concerning

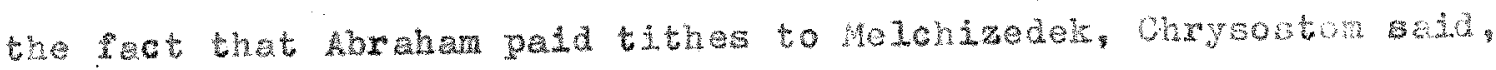

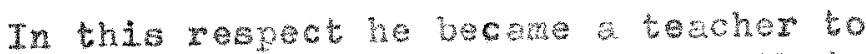
all men that by wat of declusing the

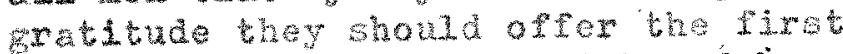
frutus of those things whel cod has granted then 3

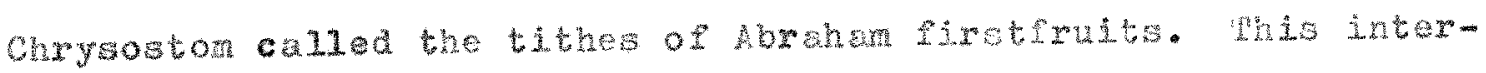
charge of terms was no doubt used by others in the eary church, honger excerpt from another of his sermons shows both

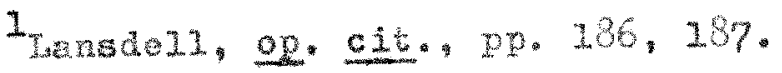

Leid. 187 .

3 John wesley Duncan, Our Christian Gberardship (Cincinnati.

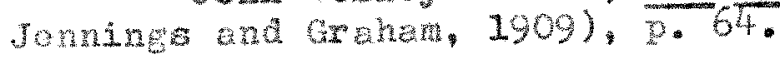


What he constered to be a New Tostament standard ent also gave an irsigit to his old restament interpretation. We revarad,

But I have also something nore to say. For except your righteoustess

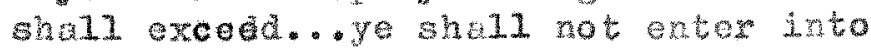
.. So, that though thou gure alma but not nore then they, thou shalt not exter in.

And how much did they bestom in

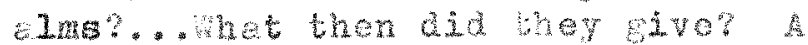
tenth of 211 their posessitons, and

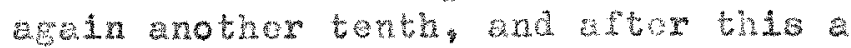
thind (tenth), so thet they almost gave way the thire part for bhree tonths put together make up this. And tougher wath these, firstExuls, and firstbon, and other things besides, for instace, the orthringe for sins, those fos puristomion, those at feastos, those in the fubiles, those by the canceling of debts, and the answase of servats, and the lendlngts that were clocr of ustry. Wut is he who gave the thint pert of his roods, or rather tho hale (for those beirg put tocether whathese oto tho half), in then he who 1 sing the hali achiever no geat thing he who doth not wostow so moh 5 the serth of mat olell he be wothy wh wer son Jesus said. Where be few thet be ared. 1

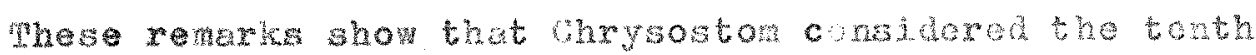

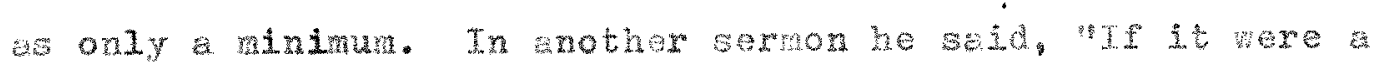

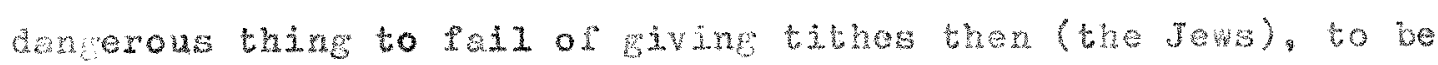
sure it is much more damperoug now" 2

Buratary. The eight men ewdied frow whe Chureh ithors

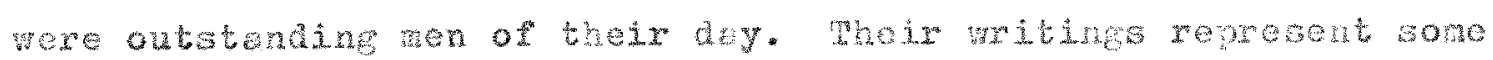

ILansde11, op. cit., pp. 200, 201 .

2.10.p. 201 . 
of the outstending thinking of the first four centurits. Wech of the ine studied malntained a frox belief in the valitity of tithing an an acceptable christian standard. Sorat of then con-

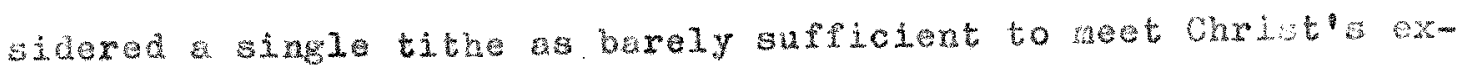
hortation that our righteousness should excect that of the phansecs. Their combined testinonies left two impressions coneorning

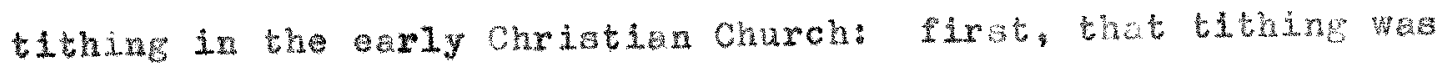
practiced by segments of the exwy church; and secordiy that whether precticad or not it should have been for the chureh to recelve cod's greater blessing on thent

\section{Church Councils}

In adation to the testimony or the church pathers thare

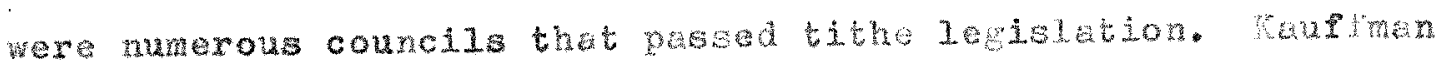
says there were ten such councila held auring tho first eight centuries. I rwo of these conncils from the sixth century, and one from the eixtecth, are noted.

Me council of Macon, 585. Fhis body met in France ond

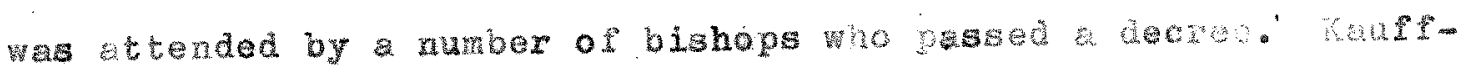

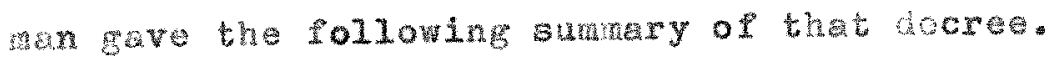

The alvine laws also taning care of the wingters of the church that thoy might have their hereditary portion, have compander 11 people to pay the bithe, that the clersy being hindered by no sort of employacht, nay be at leisure for spixtul duty of their ministy.

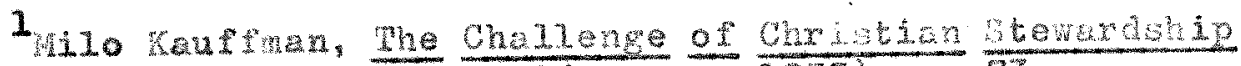
(scottdale, wennoylvania, Heradd Press, 1955), .73. 
Which lawe the whole body of christins for a long time kept inviolate, but now by degrees, aluost 11 of them have shown themselves prevarictors of those 1 aws since they neglect to tulinil the thinge which heve been divinaly commenced. 1

Whis decrea testilied to the proctice of tithing anong christine anding the eary church, but declaxed that by then (the sixth contury) the precteo had largoly declined.

ghe council of sev111e, 590. This Council was hold in spain. Kauphan gave the following extract of the council.

Let overy huberdman and overy axtisin mere a just tithing of his business. For as the Lor hath giver every-

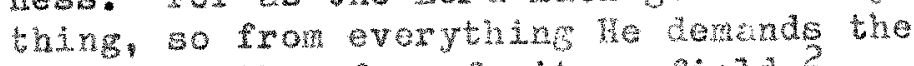
tithe, whether sron iruit or fiold. 2

mis council bejeved in tithing for men of every vocotion.

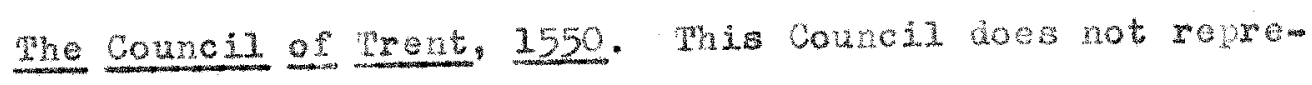
sent the exwy chutch, bet does represent an action bindng upon

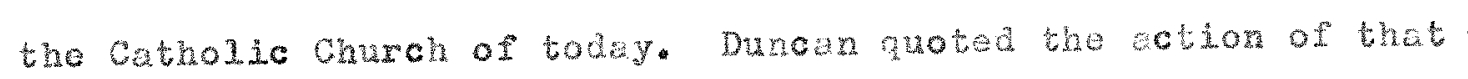
Council as follow:

whe parnert of tathes is aue to lod. and they who refuse to pay them or hindor those who wive them usure the progexty of another. Wherepore the Holy rymod enjoirs on 11 , of whatsoever rank ox cone dition they be, that they hencerom bay in full the tithes to wheh tagy are bound in 1 aw to the church, bra bhey who

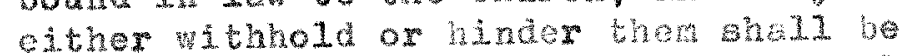
axcommancated, rox shall they be absolwed from the crime antil full restitution has bean made. 3

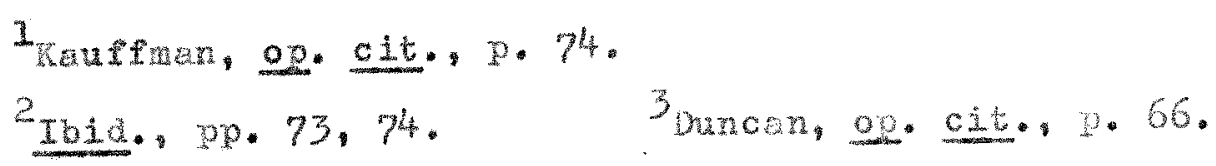




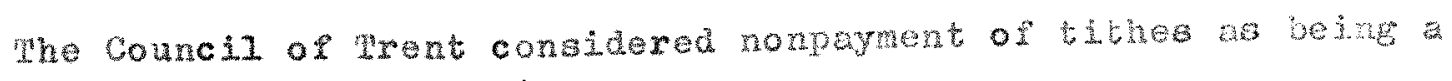
juatiable reason for excommuncetion from tho Catholic shurch. Summaty. me three Councils mentioned are recognized by

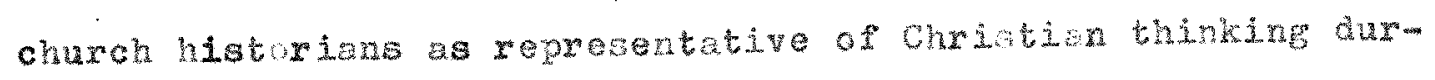

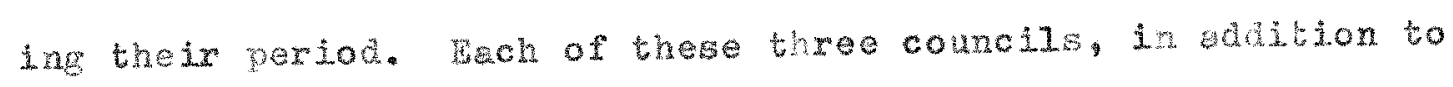
others, exjolned the proctice of tithing the cumbed testimones of outstanding church fethers and chuch councils itress to the continuziton and duty of tithing as an olement of vorship in the Christian Church. 


\section{CEAPSER VI}

SUMWAK AND COWCLUS IONS

The purpose of this thess was to pureue a Biblical study of the techinge for tithing as found in both the old ard hev

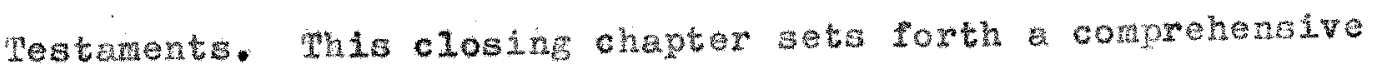

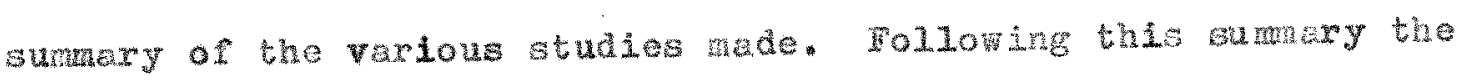

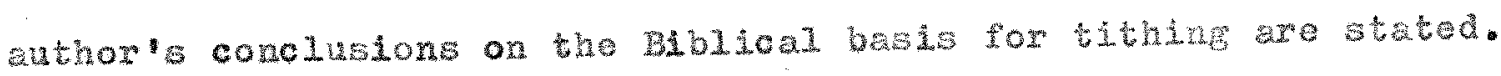

\section{Summery}

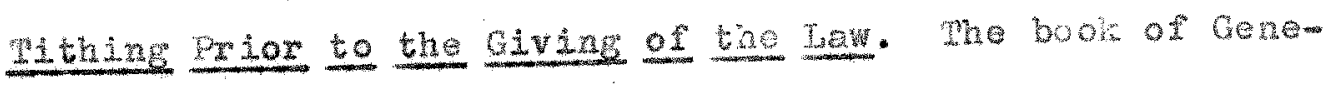
sis provides description of tithing woto to the fiving of the Law. The practice of tithing as demonstrated by a trandson Jacob establish the fact of the practice of tithing prior to the giving of the thate

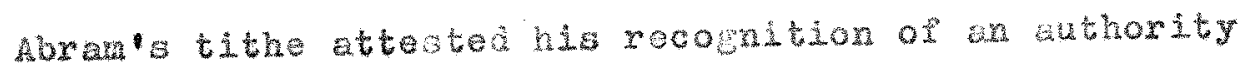

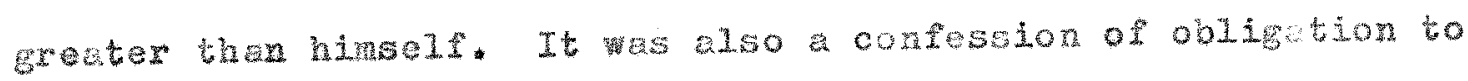

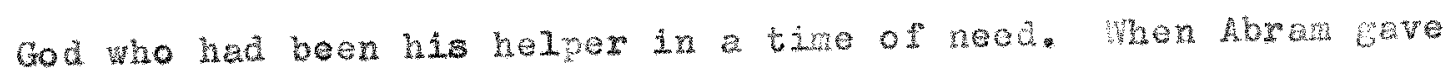

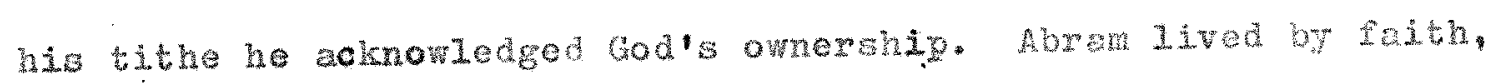

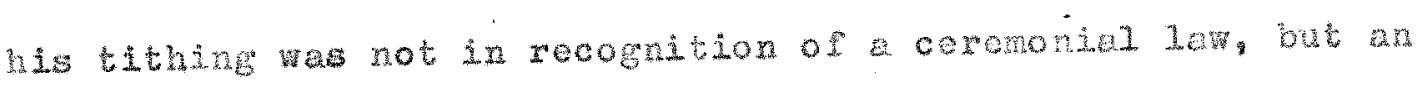
cot of woxhip and iath in God.

Jacob began tibning through wow made to God at Bethal.

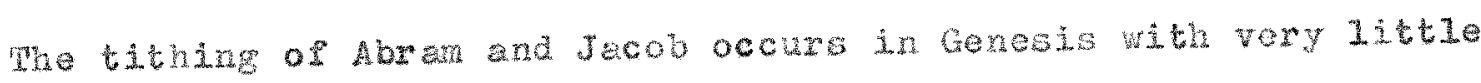
explanation, other than the imedize setsing or the events in

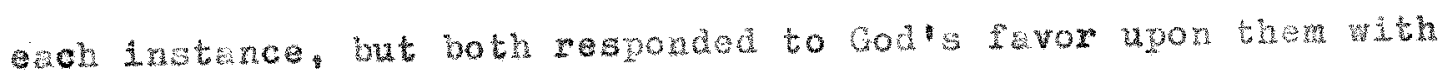
the save measure of grationde, a tenth. 
Whe practice of tithing priox to the bivine of the lat was found to be a wlespread practice among the hating of antighty.

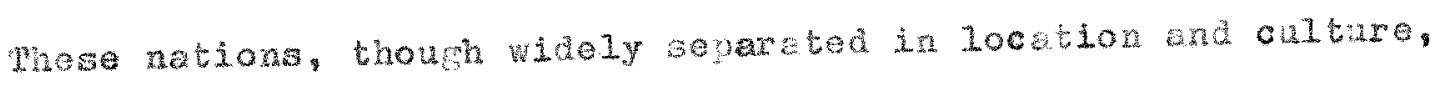

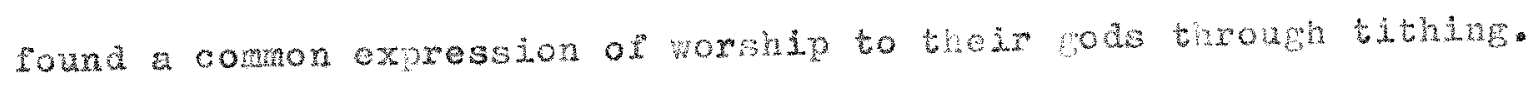

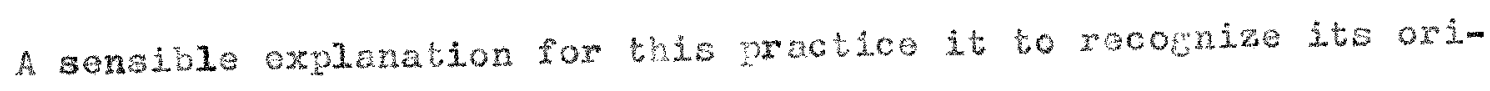
in frow God and that it wherpetuatod through the centuries wo the tine of har and and Jacob.

Hithin During the period of the Isw. A stury of the rosatc reforemces to thling in the bock of Leviticus, Mambers, and beuteronony wevaled four hisperent thes. Three of these

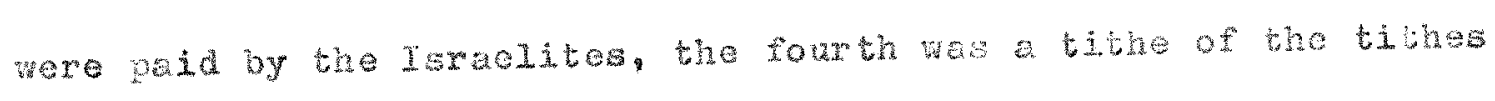

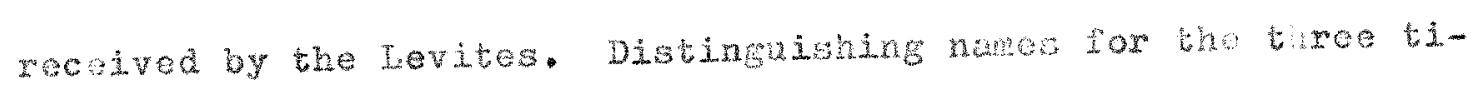
Whes were: Leviticel, Eostival and poor tithese

whe Levitical tithe was guen to the avites by God sinco

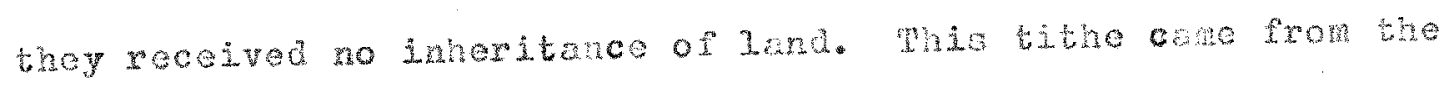
tifhes of the reed of the land, the frut of the tres, the herd ant the flocks. The nxinary function or this tithe was to prom yide for the Iivelihood of the tevites. The seviticht tithe was holy unto the lord.

The restival tithe che from the increase of the geod from the fielus, the tithe of frain, new, who, oll and the pirstings of eithor a hera or flock. The festival tithe was euten by the offerer, his howsenold and the levito. whis pestrol was observed at the contral placo of workin. The stated parpose of the fesw

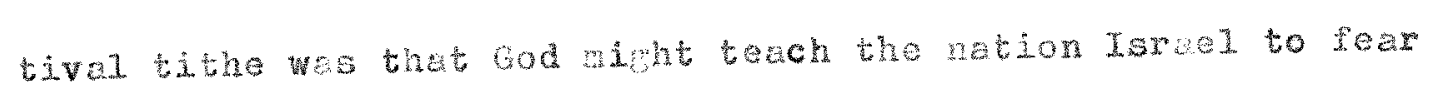
Jehoran. 
The poor tithe was observed every third year and was computed on the Isralite's increase for the third year. Whe por tithe was reserved for the wiows, fatherless, strangers and the Levites. Through this tithe cod wished to bless the labors of the poople.

The chree tithes did not ropresent the bithe of aiferent forma of increase of vealth. Mheir afforences were in the uses for which the tithes were employed. The Scriptures clearly outIne the runction fulfiled by each of the three tithes. me functions were the support of the Levites, to provide tredns for religions festivity, and to sssist the poor or the netion.

The books of the old Testartent a ter the pentateuch give aditional insignt into the tithing practices of the Isruelites. The prophets hos and Walachi, the retorner Hezekich, and the ouilder wehemah, each wrote on tithing with the conviction thet the Istaelites should tithe.

me extra-3iblical reterances of the Apocmend books of

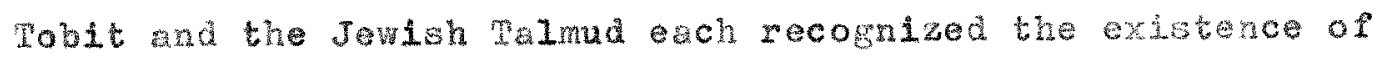
three tithes.

The Moscic lew ald not create the principle of tithinge Whe Nosale tew recogrizad ththe and related then to the coremonial law of Israel. The most signiflcant teaching concerning the tithe was its practice as a foxp of worghip. Mithing gave ta sense of partnership whth God hn the work of Wis kingdom.

rithes were always associated with the centrin place of worship, except for the poor tithe which was ket at the tither"s 
home. Whe tithes were to $x$ epresent a tanth in value, not merely

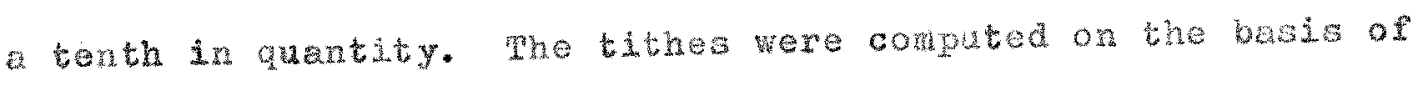
the tither's therease". An exception to this was in the withing of the herds und focks. In those instances the rula of every tenth andmal, whether good ox bad, prevalied.

cod's blossing was definitely relatod to the lsmalite's

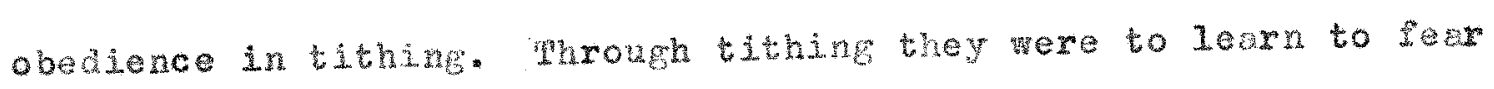
Jehoveh. Got also pronised to bless thesr labos as they titued. Whe prophet Malachi gives the best knom tishine pronise to those who would prove cod by bringing the whole tithe into the storehouse. "whose bringing in the whole tathe would have the very windoms of heaven opened upon then until they could not contain 11 of the biesing

Iithing in the New Iestumb. The ony references wo tithing in the New Testument were by Jesus to the pharisees, and a roference in the book of Hebrews. Jeaus commended the phorisees for their tathing one of the few thing they aid which met his

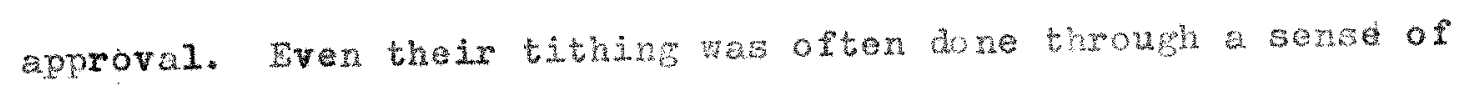
strict legelism and wh the hone of herit. Josus did not abrogate the tithe, nor destroy the woral 1 atw. His teaching exhortea his followers to 1 et their riphteousness exceed thet of the

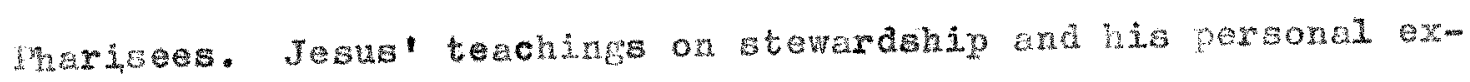
ample indicated his belief thet a mans money was orten an ina cotor of his spiritud health. Jesus aefinitely taugt that cod

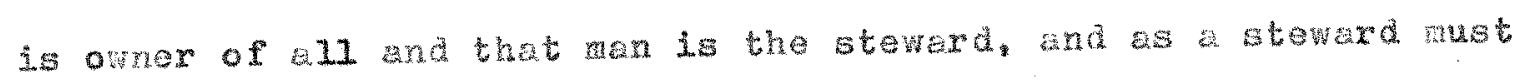

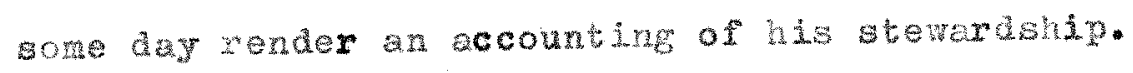


The apostle pal nevor made rention of the tithe in his whinge. However pal's testmony of his strict Jesish rearing Indicates that he was probebly a ther berore his conversion. In his letter to the Corinthian church pul stresed proportante giving according to thelr wedky increase. He bue this sane

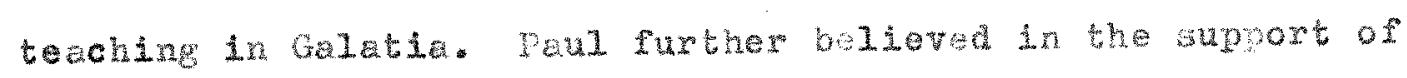
the ministry by the various churches and in arcunent for this support reminded the coranthians thet the Levites who ministered in the temole 1 ived on tathes.

Whe Hebrew epistle contains a furber discussion of the

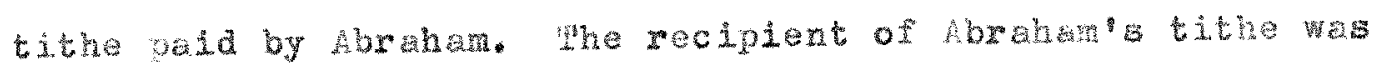
Welchizedek, a priest of the host Iigh God. Whe llebrestepiste shows Chxist to be a priest of a gatex oxder than that of the Levites. Levi pad tithos in horham. Whe argument is butold

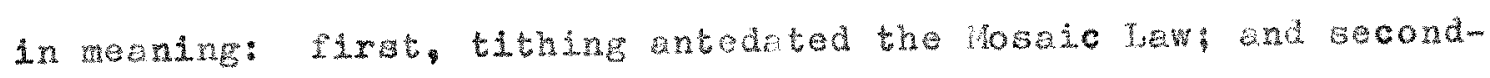
1y, Christ being a piest forever after the order of Melchizedek 18 worthy of recelving tithes.

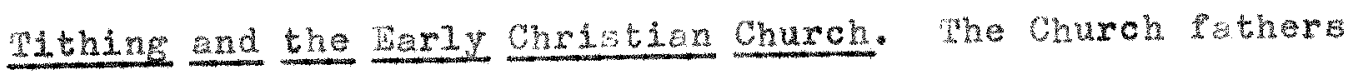
were nearly unanlwous in the guppor of tithing in the churoh.

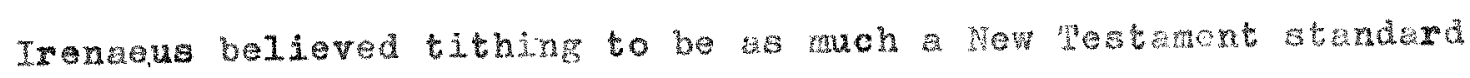

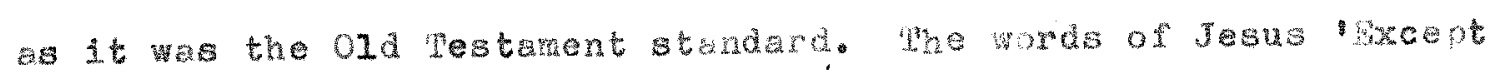
your righteousness exceed that of the pharisess, was interpreted by origen, Augustine and Chrysostom as meaning that the disolplas of christ should tithe. Cyprian strongy felt that the carey

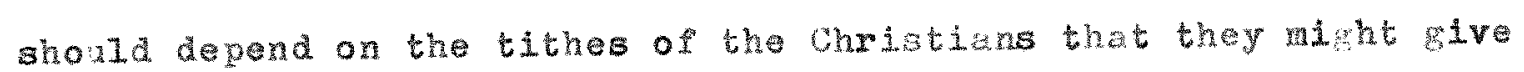

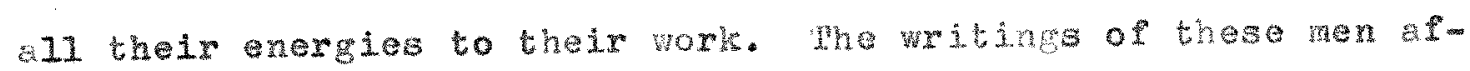

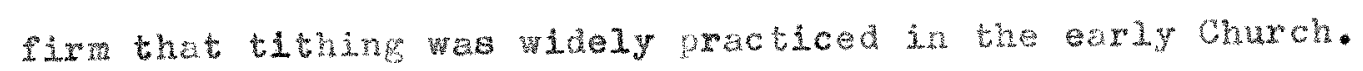


The comell of Hecon recorded the oplaton that the clergy should be supported by thes, and that in the eariy church bisey had besn. other counclis fave similar opinions. ine concins of Sevilie und went decred tithing as binding upon chrietians

\section{Conclusions}

Whe witer sought to ascertain the Biblical basis for tithage. rhe conclusions which this atudy substantates have been summarized under two divisions: the fundamental principles for ththing, and the values of tatbing.

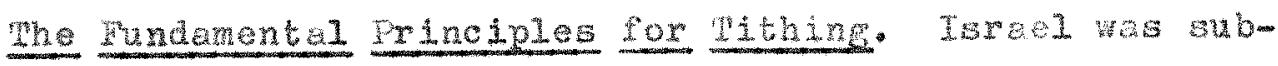

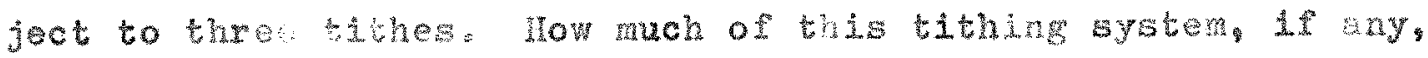

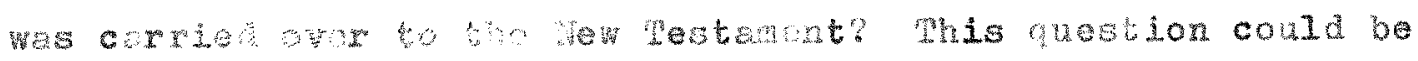
answered in three wys: none, some or all. The teviticil tithe was used to cupport the priegthood; the festival tithe in festivala and pilgrimeses and the poor bthe wos usod in the care of

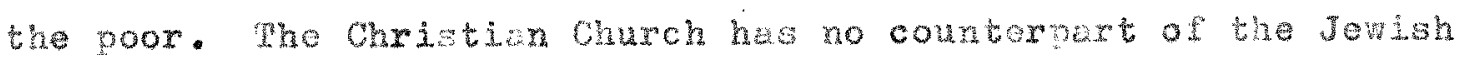
festival tithe. mhe support of the minstry and the cure of the

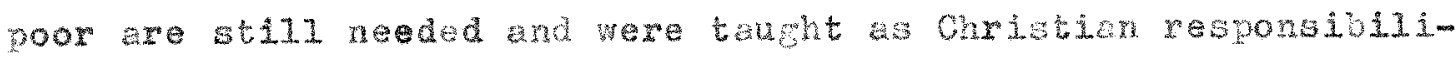

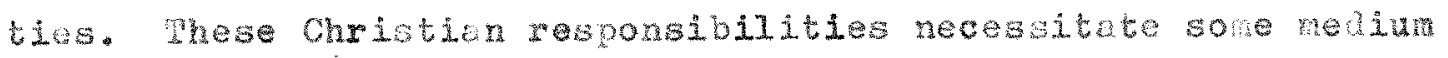
of inancial 1 waport.

Ifthing orighated in the earilest of Bible thres and was only recogmized by the Mosaic Taw. Wnder the Hosaic taw the tithing pratioe was possibly enlarged. The restival and poor to thes may have been introduced at the tine. Scripture bives no depinite ancwer to this problon. Mhe principled asocicted wh 
thing suggest several reasons sor the chrigtian observance of

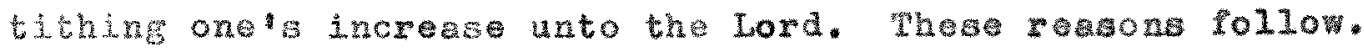
First, the Scriptures tach bhat avery Christan should Wake an aknowledgrnont of God's ownership and of Christs Lord-

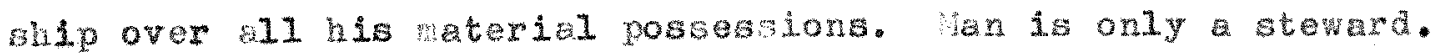
Henting is an acknowledgment of cods owmership.

secondy, this owership should be acrowledged regulariy as an act of worship. The old pestanent spoke of tithing the

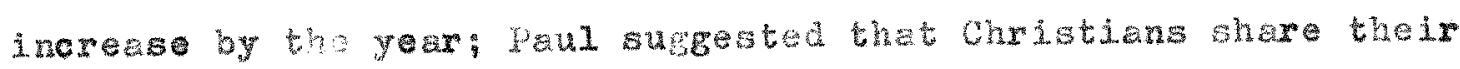
income weekly. The tither accepts God"s injunotion to "prove me nower.

Mirdly, pagan history, Bible history and chutch history al testify that cod's ownership has been acknowledged by a deprnite proportion of income. These sane three soures of nistory testify to the univasal wage or the tenth as that wroportion. Fourthy, tithing was institutod before the hosalc law hs pert of God' noral 1 aw and as an act of worship tithing contimues as an expression of devotion to God. A Christan ought to do as much under the gospel as did the Jews ander the Taw is not, the notives of the pospel must be inferior to thase of Jualasas pagandam.

Ifthy, the tithe provides an acceptable Biblical mini-

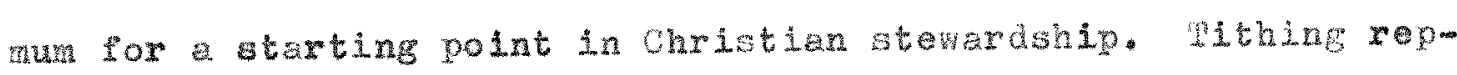
resents syotem of charch economics which is senctioned by the soriptures. The tithe expresses a solptural princlple, testifies as a christen winess, 18 token of consecration a wybol of devotion, and an adventure in bleesing through diang wa missions. 


\section{The Vazues of Tithing. The Scriptures stadied indickted} that a nuber of practical spixttual values could acorue through tithing. The dangers of tithing, such ag legaligh, pride, con-

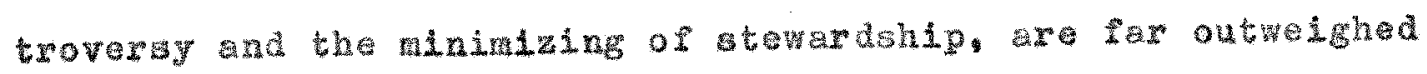
by the values.

One of the gatrest values as the realization or being usea in the suppoxt of Cod's kingon. TLthirg 1 womship and obedience, bat it is also partnership with God. Ihis we well portrayed in the daye of riag Hezekiah. Ththing can develop into

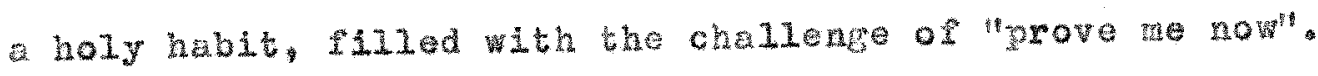

Jows continuliy teught ageinst coveteousness and greed. uthing is one of the preatest deterrents to coveteausness. In thing consisterty demands that cor be placed isst.

Tithing 1 an aid to fath; falth that cod wil cart for His ow though the nine-tenths left to the bither. In this manner tothing encourages thrist, tinancial plawing and an accurate accounting of income in order to correctiy deternine the tithe. These grinciples are inferced in the practice of tithine as D1ustrated by Bible tithers.

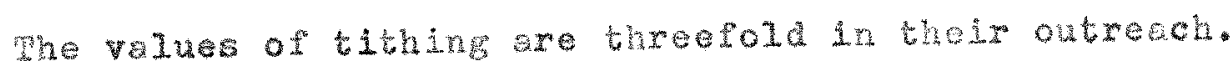

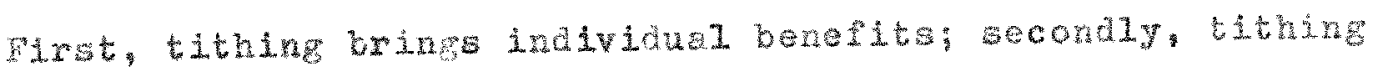

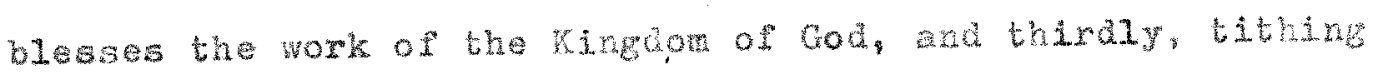
honors God with that portion which was declared to be holy unto the Iord.

A Christian should tithe, not in the hope or recelving

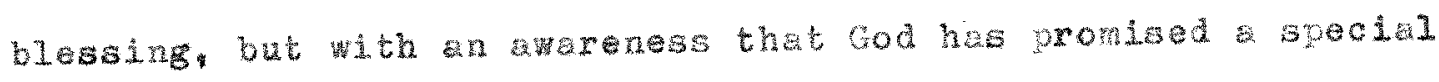
blessing to those who bring the whole tithe fnto the storkhouge. 


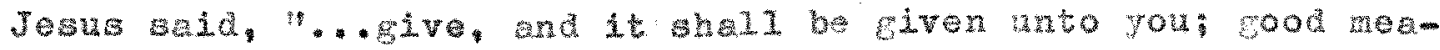

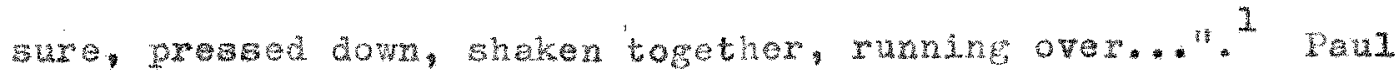

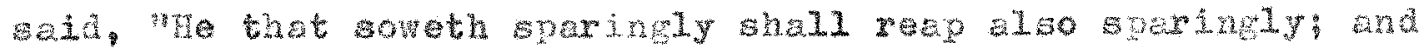

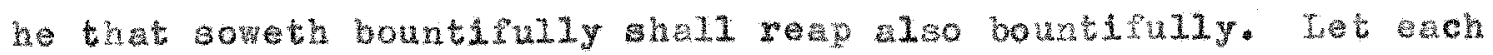
man ao acoording as he hath purposed in his beart not grudugly. ox of necesity" for God Loveth cheerul givm"

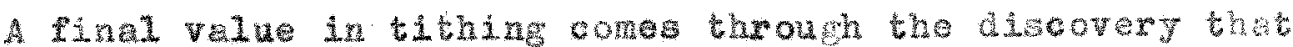

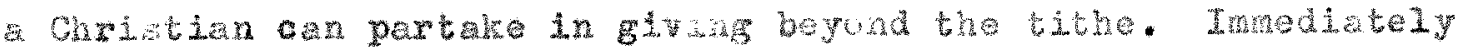

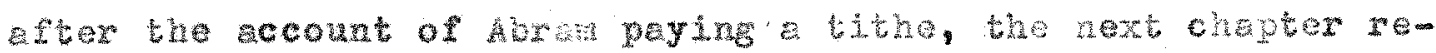

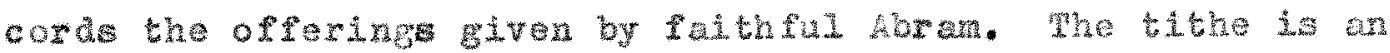

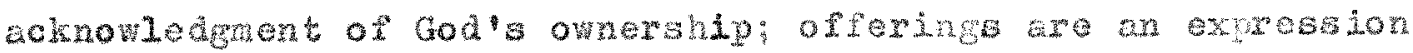
on love and devolion.

The guiring star for the hending or the ththe is found in the enduring words of seripture, "the tithe...is holy unto the $\operatorname{Lax} 6$

$1_{\text {Luke }} 6: 38$.

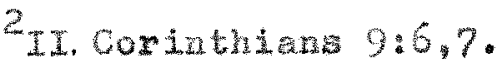




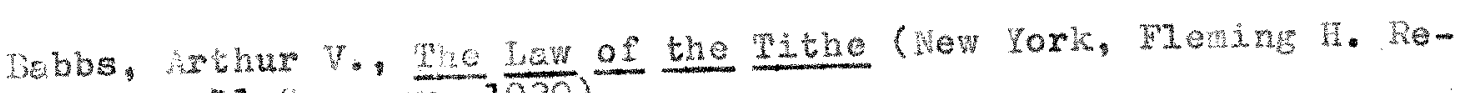
vel1 compan, 1920 ).

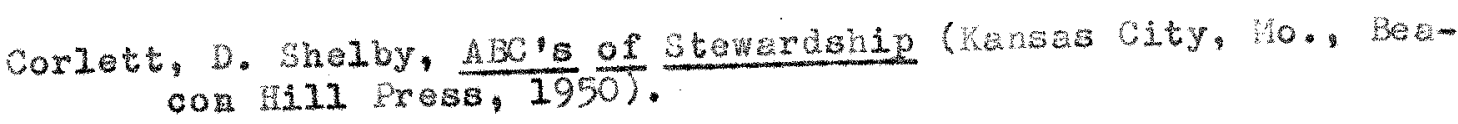

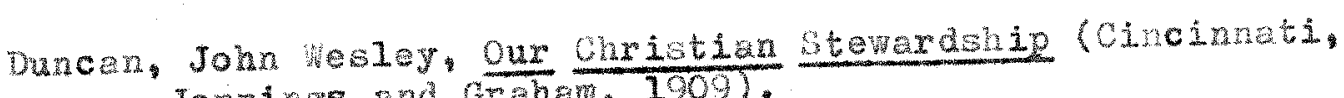
Jennjugs and Grangm, 1909 ).

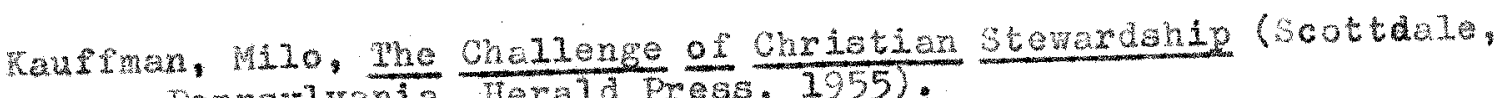
ponsylvania, Hexid Press, 1955 .

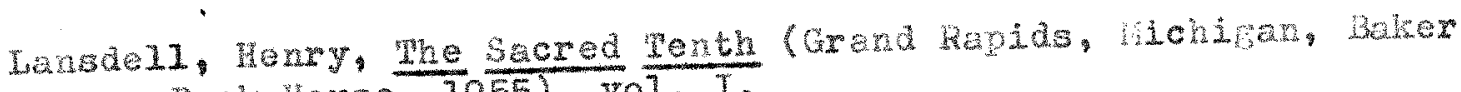
Book louse. 1955 ), vol. I.

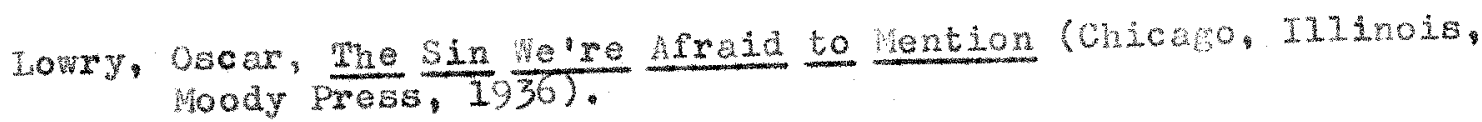

Selotrand, Goorge h. B., The pithe (Grand Rapias, Hohigan, Buke Dook touse, 1952).

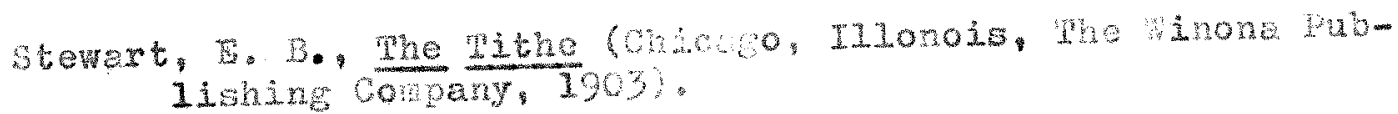

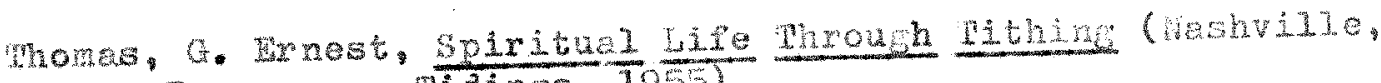
"ernessee, "itaings, $195 \%$.

Holy Bible, Maricon Standara Vursion, 1901. 


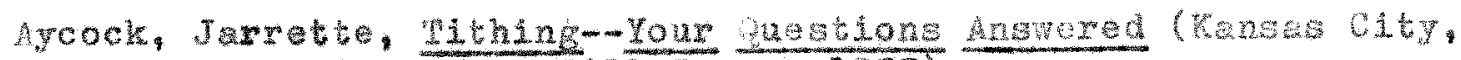

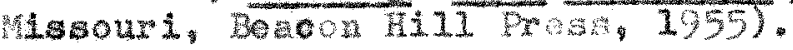

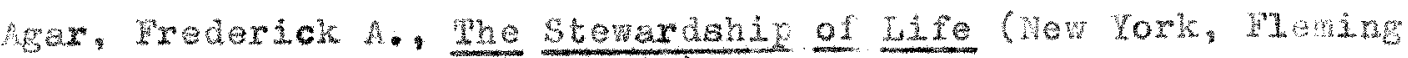
H. Revel1 Cow wary, 1920 ).

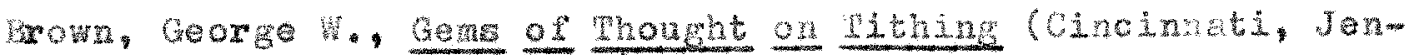
thus a

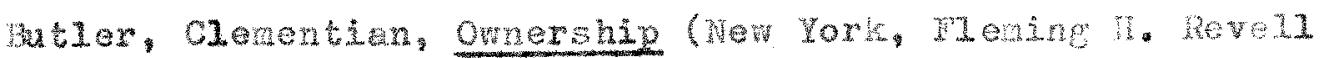
Company, 1927 .

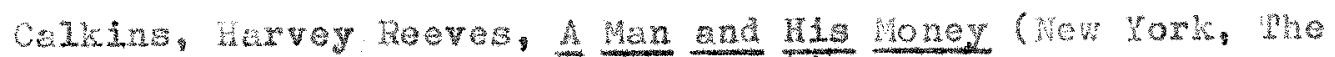
Hethodist pook concent.

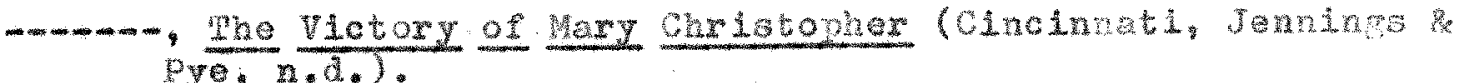

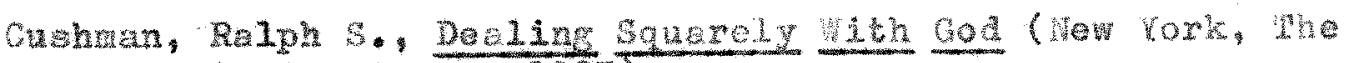

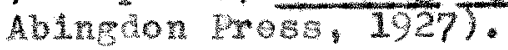

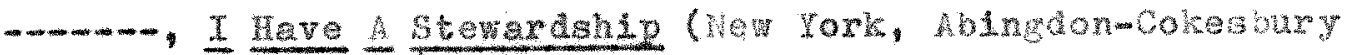
$\operatorname{pat} 1939$

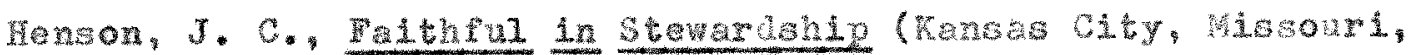

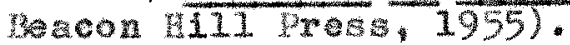

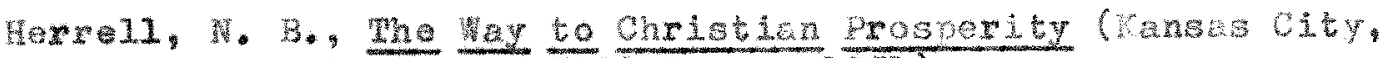

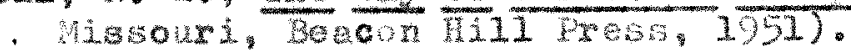

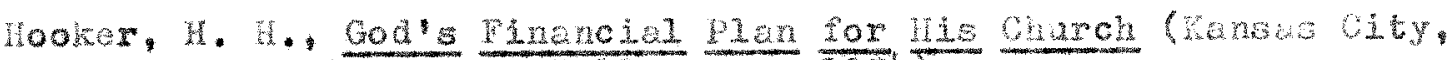

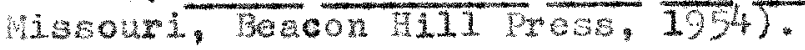

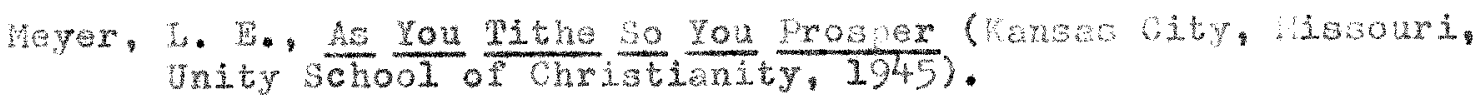

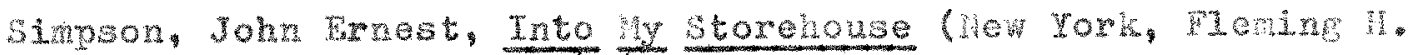
Reve 11 compary 1940 ).

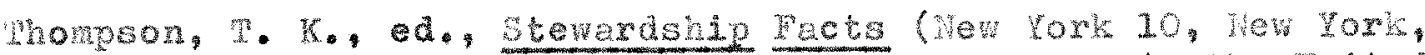
National Council of the Churches in christ in the Trited wes of America annaliy).

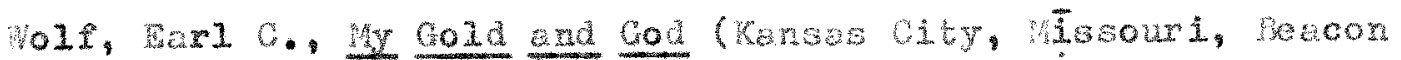

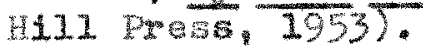




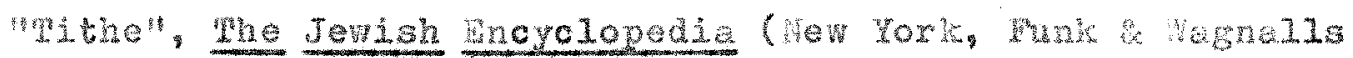
Company, 1925), XII, 150-352.

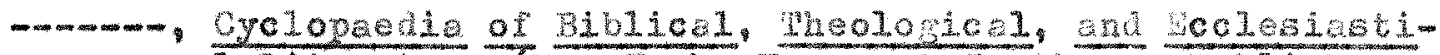

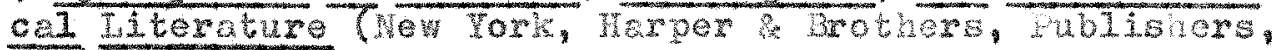
$3094, \bar{x}, 433-437$.

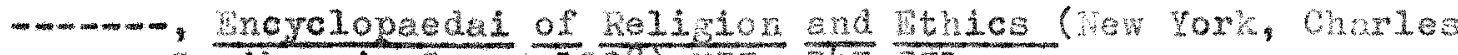

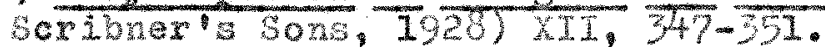

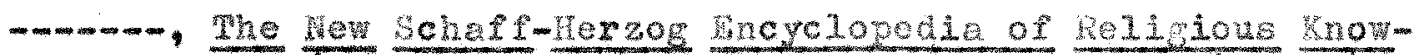

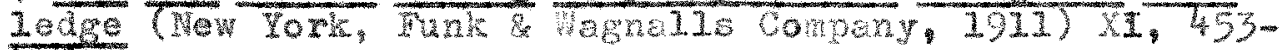
456.

panphles

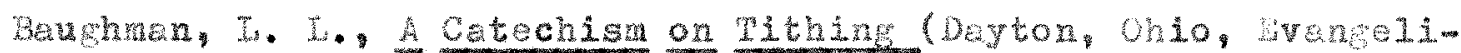
cal United Brethren (huxch).

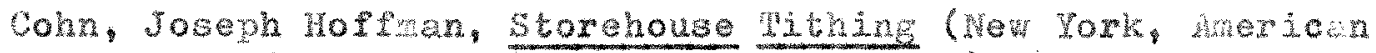
Boaxd of hissions to the Jews, Ino.).

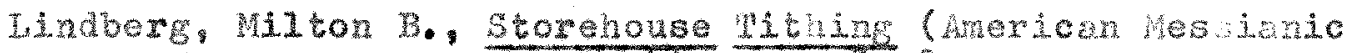
Fellowehip, June, 1954) LXIV, 33-35, 99-101.

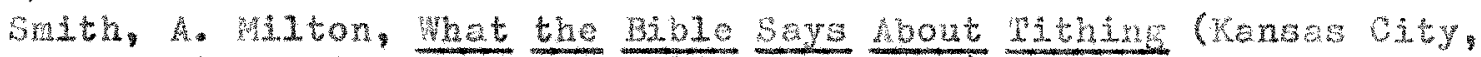

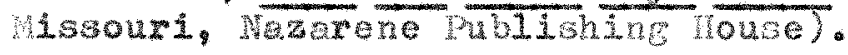

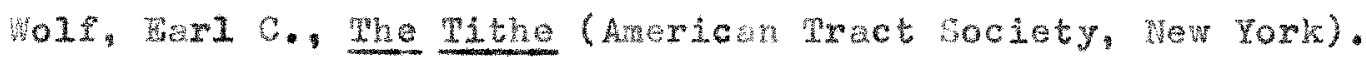

